\title{
Horror and amazement: Colossal mythological statue groups and the new rhetoric of images in late second and early third century Rome
}

\section{RALF VON DEN HOFF}

Cultural phenomena of the second and early third century CE, which are conventionally placed in the category of 'Second Sophistic', have been studied both in terms of their socio-political implications, and as a discourse of identity construction, especially among the elites of the Greek east. ${ }^{1}$ In this context, only some aspects of the visual arts have been analyzed as signs of a 'Greek Renaissance.' ${ }^{2}$ In a broader sense and as far as the city of Rome was concerned, the nexus of visual culture and the Second Sophistic was only of minor interest. ${ }^{3}$ Thus, it is still a desideratum to describe this relationship beyond references to paideia in the restricted sense of knowledge of Classical Greek culture and to concepts like 'Greek influences' or classicism, which were elements of Roman culture long before the second century CE. ${ }^{4}$ It is clear that the Second Sophistic is also defined by new interests in elaborated form, rhetorical performances and entertainment. Hence, it is fruitful to compare visual and textual phenomena in terms of their modes of depiction and means of addressing the audience - that

1 See in particular: Bowersock, 1969; Bowie 1970; Anderson, 1993; Woolf, 1994; Swain, 1996; Schmitz, 1997; Bowie, 2000; Goldhill, 2001; Stephan, 2002, 199-222.

2 Walker, 1989; see also von Mosch, 1999 (for the relevance of coins); Galli, 2001 (for sanctuaries and images of pepaideumenot); Baumer, 2001, 90-93 (for a new interest in classical votive reliefs); cf. now also Galli, 2002, and various contributions in this volume.

3 Although Rome has been called a „centre for sophists“ (Bowersock, 1969, 29; cf. Fantham, 1998, 217-225; Grüner, in print) and although the relations to sophistic circles in the east were intensive, cf. Bowersock, 1969, 43-58; 76-88; Steinmetz, 1982, 110-113; Anderson, 1990, 9899; Anderson, 1993, 31-35; for sophists and philosophers in Rome cf. Hahn, 1989, 46-53; 148-155; for Herodes Atticus in Italy see now Galli, 2002. - For phenomena of Roman art especially in sarcophagi and portraiture - in relation to the Second Sophistic see, for instance: Müller, 1994, 139-150; Zanker, 1995, 198-268; Elsner, 1998, 5; 170-185; Smith, 1998; Fittschen, 1999, 78-107; Ewald, 1999a, 14-16; Danguillier, 2001, 215-218; Fischer-Bossert, 2001, 149-152; Borg - Witschel, 2001, 112-113; Zanker - Ewald, 2004, 29; 36-39; 260; cf. Schmitz, 1997, 16; Bowie, 2000, 903. - A critical comparison of Rome and Greece in terms of 'sophistic' phenomena: Bowie, 2000, 917-921; see now Grüner, in print.

4 See esp. Zanker, 1974; Zanker, 1979; for references to paideia in the arts see n. 3 above. 
is: in terms of their rhetoric. This is the aim of my paper. Since a systematic investigation of the rhetoric of Roman art in the second and early third centuries goes beyond the scope of a single article, I shall focus upon a single previously ignored phenomenon of the Roman imagery of this period: the increasing number of colossal mythological statue groups in Rome. 'Mythological statue group' refers to a set of statues produced together and depicting figures acting with reference to one another, thus narrating a section of a myth - in contrast to action-less single statues or paratactic groups. The category 'colossal' refers to figure-sizes that go beyond what could still be taken as life-size from the usual viewing distance of a few meters; that is, beyond a height of $2.5 \mathrm{~m}$ per group approximately. ${ }^{5}$ How do colossal mythological groups testify to a specific rhetoric of images? Can they be analyzed in relation to the contemporary debates and techniques of presentation which were important in the Second Sophistic?

Life-sized mythological statue groups had been familiar in Rome since the Hellenistic period, and remained on public display in sanctuaries and porticoes throughout the imperial period. ${ }^{6}$ In imperial times, they also featured in state monuments, thermae and horti. ${ }^{7}$ In contrast to this, the number of mythological groups in private, non-imperial Italian villas in the early imperial period is small. ${ }^{8}$

5 This is slightly different from the ancient category 'colossal', which means multiple life-size (Fittschen, 1994, 612-613; cf. Cancik, 1990; Kyrieleis, 1996, 91-96), but fits real criteria of perception better.

6 See in particular the Greek originals: Achilles-Chiron and Pan-Olympos: Plin. NH 36.29; 36.37; Mart. 2.15.5-6; cf. LIMC 1, 1981, 48 s.v. Achilleus no. 50 (Kossatz-Deissmann, A.); Leibundgut, 1999, 373-374. - Pan-Olympos luctantes: Plin. NH 36.35. - Achilles receiving weapons from Thetis: Plin. NH 36.26; LIMC 1, 126 s.v. Achilleus no. 535 (KossatzDeissmann, A.). - Niobe and her children: Plin. NH 35.28. - Cf. also Pape, 1975; Vermeule, 1977, 45-64; Ridgway, 1985, 109-111. - Cf. Vorster, 2003.

7 For example: 1) Imperial monuments: LIMC 2, 1984, 860-861 s.v. Askanios A/B no. 1-8 (Paribeni, E.); de la Barrera - Trillmich, 1996 (Aeneas, Anchises and Askanius, Forum Augustum). - 2) Horti: Cima - La Rocca, 1998; Talamo, 1998, 113-169; Moltesen, 1998, 180-188 (Artemis-Iphigeneia; Niobe and her children; Leda-swan); Geominy, 1984, 30 (Niobe and her children); Vorster, 1993, 21 no. 3 (Marsyas); LIMC 6, 1992, 919 s.v. Niobidai no. 23 b2 (Niobe and her children) (Geominy, W.); cf. also Cima - La Rocca, 1986; Häuber, 1991; Andreae, 1993, 130; Graepler, 2002; Hartswick, 2004. - 3) Thermae: cf. Manderscheid, 1981, 73 no. 44-45; no groups and almost no testimonia from Rome itself; for the provinces see below n. 56. - See also the collections of art like Asinius Pollios' monumenta with the original of the 'Farnese Bull': Plin. NH 36.33-34; Pape, 1975, 177-179; La Rocca, 1998, 236-247; Kunze, 1998, 39-42; 92-93; Stähli, 1998.

8 Only one example in Neudecker, 1988, 44; 162 no. 21, 5 (Actaion, Lanuvio); one could add the small terracotta groups from Tivoli (Andreae, 1996, 200-207; 239 n. 4, 3) and Tortoreto (Andreae, 1996, 210-219; 244 no. 4, 5); I leave out dionysaic groups, which imply no distinct mythological narrative, cf. Neudecker, 1988, 47-54; 241-242; Stähli, 1999, 15-41, with further examples. - Later examples see below n. 18. - In villas, paintings or reliefs were used instead of statues to present narratives: Neudecker, 1988, 44. 
However, it is interesting that, in the first century CE, these statue groups often appeared in very rich or even imperial villae or palaces. ${ }^{9}$ Sometimes, as in Sperlonga, they were artificially embedded in the landscape, or grouped in cycles representing events from epic, thus expanding their narrative potential. Some of these groups reached colossal size. In the late Republic, the existence of over life-sized groups in rich Italian villae is shown by extant marble figures of Greek heroes in action, around $2.10 \mathrm{~m}$ high. As part of the Antikythera shipwreck they were destined for rich customers in Italy. ${ }^{10}$ Collectively, these figures show that life-sized mythological statue groups were common in Rome's public sphere from the late Republic on, but remained rare in the private realm through the early imperial period. The display of elaborate, colossal examples was a peculiar feature of rich and/or imperial villas in Italy through the first century CE. These statues exceeded what was known in the public sphere. ${ }^{11}$

On the other hand, colossal single statues were nothing astonishing in the urbs: In keeping with Greek traditions, cult statues of gods and heroes were often of this size. ${ }^{12}$ Likewise, portrait statues of the emperor could reach colossal proportions, ${ }^{13}$ as could idealized statues in the realm of the emperor. ${ }^{14}$ Hence in Rome, during the first century CE, colossal statue size was a privilege of images of gods and emperors, and of statues in the emperor's realm. Their colossality created an impression of power and divinity, surpassing the human sphere. ${ }^{15}$

The second century saw change in this system. Mythological statue groups were still common in imperial villas. ${ }^{16}$ Even during the following decades, they

9 Rome, Palace of Titus (Laokoon): Plin. NH 36.37; Himmelmann, 1991; La Rocca, 1998, 220228; Andreae, 2001, 188-194 pl. 182-183; Stewart, 2003, 494-513. - Subiaco (Niobids): Neudecker, 1988, 224 no. 63, 1-3. - Castelgandolfo: Neudecker, 1988, 44-45; 139-144 no. 9; Andreae, 1996, 332-341; 371; Gregarek, 1999, 253-254 no. E55. - Baiae: Andreae, 1996, 316-331; 366-369; Andreae, 1999, 225-241. - Sperlonga: Neudecker, 1988, 44-46; 220-223 no. 62; Himmelmann, 1995; Kunze, 1996; Andreae, 1996, 270-315; 346-364; Andreae, 1999, 177-222; Ridgway, 2000; Andreae, 2001, 121-131 pl. 98-102; 147-151 pl. 122-125.

10 Bol, 1972, 78-83 no. 28-31 pl. 44-50, 3; Himmelmann, 1995, 17; 35; 42 with n. 71 pl. 36-37.

11 Cf. Himmelmann, 1995, 17; 36-38, who rightly denies that colossal size was an imperial privilege.

12 Jucker, 1950, 44-48; Martin, 1987.

13 Nero: Bergmann, 1993; 1998. - Domitian: Stat. Silv. 1.1; Stemmer, 1971, 563-580. - Kreikenbom, 1992, with review: Fittschen, 1994.

14 Cf. the colossi from the Palatine: Belli Pasqua, 1995, 89-90 no. 37 pl. 42-44; $98-99$ no. 55 pl. $57-$ 60; Gregarek, 1999, 85; 210 no. D1 fig. 60; 98; 247 no. E20 fig. 88.

15 Cancik, 1990. - Colossal size had been a sign of heroic status since the Archaic period: Kyrieleis, 1996; cf. Philostr. Her. 7.9.

16 Villa Hadriana, Tivoli: Raeder, 1983, 31 no. I 2; 40 no. I 12; $43-44$ no. I 18; 96 no. I 99; $102-$ 103 no. I 118; 106 no. I 124; 143 no. III 3; 169 no. III 79; 170 no. III 85; Kunze, 1988, $220-$ 221 (Niobids); Vorster, 1993, 77-81 no. 29 (Niobids); Andreae, 1996, 342-345; 372-375 (Scylla); Gregarek, 1999, 252 no. E51 (Niobids); LIMC 6, 1992, 919-920 s.v. Niobidai no. 23 
did not vanish, as has been claimed. ${ }^{17}$ Instead, they appeared more often in nonimperial villae, both in Italy and in the provinces..$^{18}$ These groups are rarely more than slightly over life-sized; but in the second century, colossal groups appear also for the first time in the public areas of Rome. The two marble Dioscuroi taming their horses which today dominate the Quirinal hill in Rome, reach 5.60 $\mathrm{m}$ of height. ${ }^{19}$ Stylistically they have recently been dated to the end of the second century CE. Hercules wrestling Antaios (fig. 2) is a colossal mythological group (around $2.90 \mathrm{~m}$ high) from around $200 \mathrm{CE}$. It came from Rome to the Palazzo Pitti in Florence. ${ }^{20}$ Although we do not know the provenance of the second century colossal fragments of a satyr and a maenad in Venice, they provide additional evidence for the now increasing number of such groups. ${ }^{21}$ Other colossal statue groups come from a single archaeological context: the Baths of Caracalla (211/2-217 CE). ${ }^{22}$ The 'Farnese Bull' (fig. 4) is the most spectacular. ${ }^{23}$ Measuring

a3, b4, c4, e1 pl. 615, e2, k5, n pl. 616 (Geominy, W.); cf. also the imperial villa in Anzio (Neudecker, 1988, 133 no. 2.16; 2.17; Gregarek, 1999, 254 no. E57); cf. for sculptural display in Hadrian's villa now: Newby, 2002b.

17 Andreae, 1993, 123; 130: „Auslaufen dieser Kunstgattung unter Hadrian.“

18 Examples: 1) Italy: Neudecker, 1988, 134 no. 3. 1; 3. 6; 169 no. 25. 6; 25. 10; 213 no. 54, 6; 187 no. 37, 19 (Triopion of Herodes Atticus; cf. Galli, 2002, 110-143); 215 no. 56, 1; 212 no. 53.2; 53.3 (possibly imperial; cf. Moreno, 1995, 366-369 no. 6.11.3; 6.11.4); 182 no. 35, 16. 2) Provinces: Luku: Spyropoulos, 2001, 131-132 no. 1 pl. 5-8; for other finds from this villa and from other villae of Herodes Atticus cf. Tobin, 1997, passim, esp. 333-354; Galli, 2002, passim. - Valdetorres: Gregarek, 1999, 169 no. A1, A2; 253 no. E 52; 244-245 no. E10; De Nuccio - Ungaro, 2002, 305-307 no. 6-7. - Cf. also: Neudecker, 1988, 43-44 with n. 424 (group of Adonis and Aphrodite from Montmaurin/Gaul), Apul. Met. 2.4.10 (imagined group of Diana and Actaion in a Roman house in Greece).

19 Lorenz, 1979, 46-47; Geppert, 1996a, 64-68; 156 no. P 32; Geppert, 1996b, 133-147 pl. 78-92 (with convincing date). - Cf. the Capitoline Dioscuroi (Lorenz, 1979; Geppert, 1996a, 41-44; 155-156 no. P 31; Geppert, 1996b, 121-133 pl. 67-77).

20 Möbius, 1970, 39-47 pl. 34-37; LIMC 1, 1981, 808 s.v. Antaios I. no. 60 pl. 656 (Olmos, R. Balmaseda, L.J.).

21 Venice, Museo Archeologico inv. 39; 63: Traversari, 1986, 70-77 no. 22-23; Geominy, 1999, 142 with n. 18; R.M. Schneider has discussed them in his unpublished 'Habilitationsschrift' (Heidelberg). - Cf. also the colossal Roman Marsyas (?, from a group?) in the Villa Borghese: Arndt, 1893-1939, no. 2712; Helbig ${ }^{4}$ II no. 1944, with a replica in Antalya from Perge (unpublished: I owe these references to Adrian Stähli and Sascha Kansteiner).

22 DeLaine, 1997; Piranomonte, 1998; 1999. - Sculptural finds: Vermeule, 1977, 58-63; 109-113; Manderscheid, 1981, 73-76; Marvin, 1983; Gasparri, 1983-1984; Jenewein, 1985; 1986; 1996; Di Mino, 1991; DeLaine, 1997, 265-267. - A marble gigantomachy adds to the mythological groups (below n. 23, 26, 27): Jenewein, 1985, 18-22 no. 2-3 fig. 3-6. - I plan to discuss the sculptures from the Baths of Caracalla in detail elsewhere.

23 Naples, Museo Nazionale inv. 6002: Vermeule, 1977, 109 no. 2; Manderscheid, 1981, 75 no. 63 pl. 18; Marvin, 1983, 367-368 fig. 20; Kunze, 1988, 222-224; Pozzi, 1991; Himmelmann, 1995, 33 with n. 59; DeLaine, 1997, 266 no. 14; La Rocca, 1998, 239-274; Kunze, 1998 (with bibliography); Andreae, 2001, 160-163 pl. 135-137; Kunze, 2002, 58-60; Stewart, 2003, 510513. 
$3.70 \mathrm{~m}$ in height, it shows the dramatic punishment of Dirke: Amphion and Zethos are tying her to a bull, which will drag her to death, because she had planned to murder the brothers' mother, Antiope. The 'massif in marble' is carved - sensationally - out of a single piece of marble, something only the emperor could afford. The group is most probably a Roman copy produced for the baths. ${ }^{24}$ While the 'Farnese Bull' stood in the eastern palaestra, ${ }^{25}$ the corresponding position in the baths' western palaestra was filled by another colossal group. Evidence for its existence can be derived from an anecdote about fragments of a big marble ship and 'island' found in this area. Scylla and Odysseus' ship or the ship of the Argonauts are possible explanations. ${ }^{26}$ In 1901, a colossal left hand clasping a child's left foot was found beneath the floor of the central hall (frigidarium). It belongs to the almost $2.90 \mathrm{~m}$ high marble statue of a warrior holding a child by the foot, slung over his back (fig. 5-6). This statue, now in Naples, has been known since the $16^{\text {th }}$ century, when its head, arms and legs were restored. ${ }^{27}$ The left hand confirms the statue's provenance and makes minor changes to the old reconstruction necessary (ill. 1). The group's late second or early third century date is undisputed. The warrior depicted possibly held a sword in his right hand. On the child's right side, blood oozes from a wound (fig. 6). Miranda Marvin recognized Achilles and the dead Troilos, because Astyanax, who is often depicted in the same manner in classical art, was not dead when Neoptolemos threw him from the walls of Troy. ${ }^{28}$ But for an ancient viewer, looking at the main figure's front (ill.1; fig. 5), neither the wound nor the closed eyes of the boy could be recognized. Not until he walked around the statue, would the impious nature of the scene become clear (fig. 6):29 The corpse of a small boy, already dead, is being dishonored. Presenting furor as an intense visual experience, and evoking the viewer's activity by making him walk around in order to understand

24 Marvin, 1983, 380-381; Kunze, 1998, 36-38, contra Andreae, 1993; La Rocca, 1998 (with bibl.).

25 Its exact location in the palaestra is disputed: Marvin, 1983, 367-368; Zanker, 1991, 43-44; Kunze, 1998, 5-6 pl. 4 b.

26 Vermeule, 1977, 109 no. 4A; Marvin, 1983, 368; Zanker 1991, 46; Kunze, 1998, 5-6.

27 Naples, Museo Nazionale inv. 5999: Welcker, 1849, 371-374; Rossbach, 1895, 240-243 pl. 4; Savignioni, 1901, 252-253 no. 3 fig. 3 (left!! hand with foot); Arndt, 1893-1939, no. 29412942; Künzl, 1968, $94-97$ fig. 12; Künzl, 1969, 390 fig. 37; Vermeule, 1977, 109 no. 4; Manderscheid, 1981, 75-76 no. 64 pl. 18; Marvin, 1983, 358-363 ill. 5-6; fig. 8-11; Di Mino, 1991, 18 fig. 7-8; Gallottini, 1995, 56-58 no. 25; DeLaine, 1997, 266 no. 4; Kunze, 1998, 38 n. 173; LIMC 4, 1988, 489 s.v. Hektor no. 52 (Touchefeu, O.).

28 Neoptolemos hurling Astyanax: LIMC 1, 1984, 931-933 s.v. Astyanax I (Touchefeu, O.). Achilles hurling Troilos: LIMC 1, 1981, 87-88 s.v. Achilles, especially Achilles no. 359 pl. 93; no. 367 pl. 94 (Kossatz-Deissmann, A.). - Cf. von den Hoff, in print.

29 Cf. Künzl, 1968, 96-97. 
the image, were the aims of this group. Previously, such a scene had not been depicted in sculpture, to say nothing of its colossal size and public display.

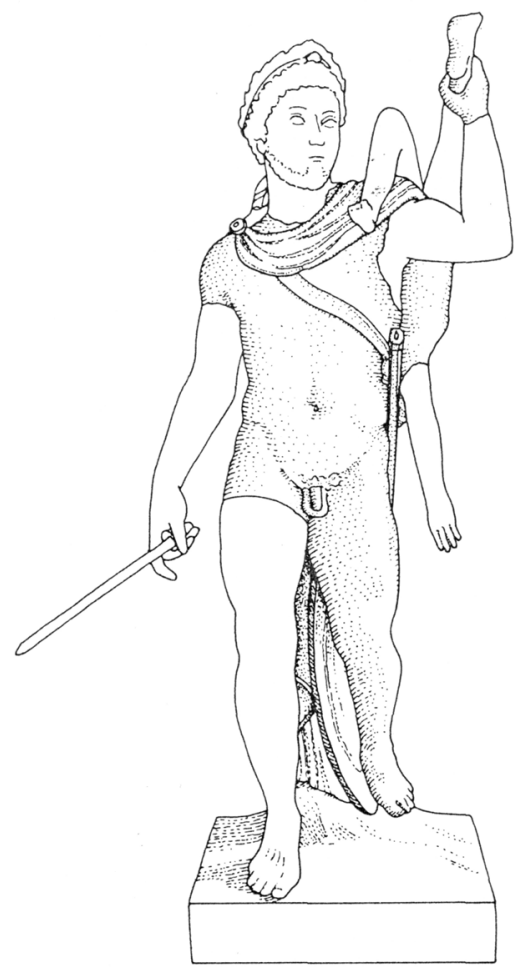

Ill. 1: Achilles hurling Troilos (?). Marble, early third century CE. Naples, Museo Nazionale 5999.

Reconstruction drawing: Marvin, 1983, 360 ill. 5.

Two unpublished marble fragments of colossal proportions provide further evidence for the growing number of colossal mythological statue groups in the late second/early third century. Originally from Rome, they are now in the collection of Schloss Fasanerie in Eichenzell near Fulda. ${ }^{30}$ The larger fragment is the body of a dead boy, whose lifeless arms and legs are hanging down (fig. 8-9). A left

30 Eichenzell, Schloss Fasanerie AMa 41 (left hand, measuring $0.27 \mathrm{~m}$ between thumb and little finger, with boy) and AMa 42 (right hand, preserved length $0.40 \mathrm{~m}$ ), bought by Prince Philipp von Hessen in Rome in the early twentieth century. The deep drill-holes in the boy's hair are typical features of late second and early third century workmanship, cf. Fittschen - Zanker, 1985, no. 80 pl. 98 ; no. 82 pl. 101. The publication of these fragments in a catalogue of ancient sculpture in Schloss Fasanerie is in preparation. 
hand, more than double life-size, is holding the limp corpse. Along with this fragment, a right hand of the same marble and size was acquired. A dowel hole in its palm is evidence that an attribute was originally attached. The only exact iconographical comparandum for the larger fragment is a Faliscan bell-krater of the fourth century BCE showing Medea fleeing in a chariot with both her murdered children in her hands (fig. 10) ${ }^{31}$ - Detailed arguments for the reconstruction have to be postponed until its final publication. But considering the vase-image and other depictions of Medea, like those on Roman sarcophagi of the late second century CE (fig. 11) 32 , it appears that the Fasanerie fragments belonged to a group of around $3 \mathrm{~m}$ in height depicting Medea, who stood free with one of her murdered sons in her left hand and a sword in her right. The other boy was either lying dead on the ground, or standing beside his mother, about to be killed. Hence, Medea, in the middle of her furor and before she finally abducts the corpses, was staged here.

Medea was a common subject of Roman mythological imagery. In wall paintings from Pompeian houses, the moment before the children's murder was illustrated, adopting the theme of a famous painting by Timomachos in the Forum of Caesar. ${ }^{33}$ Epigrams indicate that Medea's hesitation between vengeance on Jason and parental affection was the most admired feature of this painting: suspense in a moment of indecision. Later, in the second half of the second century, on the Roman sarcophagi mentioned above, we see Kreusa, Jason's new wife, and Kreon, her father, both dying as a result of Medea's poisoned gift. In

31 Red-figured Faliscan bell-krater, St. Petersburg, State Hermitage Б 2083: LIMC 6, 1992, 392 s.v. Medeia no. 39 pl. 199 (with further bibl.) (Schmidt, M.); cf. the south-Italian statuette fragment in Bonn: LIMC 6, 1992, 392 s.v. Medeia no. 40 pl. 199 (Schmidt, M.). - The identification of other infanticide scenes is difficult because of completely differing iconographies, such as Niobe (LIMC 6, 1992, 910 s.v. Niobe no. 3-9 pl. 609-610 (Schmidt, M.); LIMC 6, 1992, 914-929 s.v. Niobidai (Geominy, W.), Opheltes (LIMC 2, 1984, 473 s.v. Archemoros no. 9 pl. 357 (Pülhorn, W.)), madness of Heracles (LIMC 4, 1988, 835-836 s.v. Heracles no. 1684-1689 (Boardman, J.)), madness of Lycourgos (LIMC 6, 1992, 311-313 s.v. Lykourgos I no. 12-30 pl. 158-160 (Farnoux, A.)), Achilles with Troilos and Neoptolemos with Astynanax (above n. 28) or Athamas and Lykophron (LIMC 2, 1984, 951 s.v. Athamas no. 5-7 [Schwanzar, C.]). - On an Apulian vase fragment we find an almost comparable motive, but it is too fragmented to identify the myth: Cambitoglou - Chamay, 1997, 296-297 no. 130 (Opheltes?, certainly not Medea).

32 LIMC 6, 1992, 393 s.v. Medeia no. 50-60 pl. 200-201 (Schmidt, M.); Gaggadis-Robin, 1994; Zanker - Ewald, 2004, 82-84; 336-341.

33 Wall-paintings and Timomachos: Plin. NH 35.136; AP 16.136; Simon, 1954, 216-221; Gaggadis-Robin, 1994, 171-172; LIMC 6, 1992, 388-389 s.v. Medeai no. 7-14 (Schmidt, M.). - Cf. other epigrams on images of Medea: AP 9.593; 16.135-143; Anthol. Lat. 102 (91 ed. Shackleton Bailey); cf. Schneider, 1998; a painting of Medea is imagined in Lucianus Dom. 31. - Cf. Medea in ancient literature: Arcellaschi, 1990; 1996; Clauss, 1997; Corti, 1998; Gentili - Perusino, 2000. 
addition, Medea is shown before her children's murder, and while fleeing with her dead children (fig. 11). Here, in a funerary context, she is bringing multiple and sudden death. The moments before and after her furor and its consequences are focused upon..$^{34}$ On the other hand, we know of only two Roman images depicting Medea actually carrying out the murder: an early imperial ringstone, and a high imperial relief from a grave monument in Gorsium/Moesia. ${ }^{35}$ It appears that this brutal scene was avoided in Roman sculpture. Thus, like the Achilles-group, the Fasanerie-group represented something completely new. Medea in the midst of her furor must have challenged the viewer, who had to come to terms with this situation of horror, rather than with the problem of her indecision as depicted in earlier images. ${ }^{36}$

Both the dimensions of the Fasanerie Medea and its provenance from the city make it highly plausible that a public place or building such as the thermae was its original location. ${ }^{37}$ Considering the above mentioned groups of this period, the question arises concerning what the reasons were for setting up statues of this size and of such horrific scenes in the public sphere. To begin with the colossal scale, as we have argued above, colossal mythological groups had previously been the privilege of luxurious and often imperial villae. Colossi had an aura of power and divinity. Thus, to present such groups in public meant to bring hitherto exclusive luxuria to the plebs and, compared with life-size statues, to enhance the awe everyone would feel regarding these sculptures. The fact that Rome's thermae were imperial donations meant that it was the emperor himself who provided these objects. Thus, the Baths of Caracalla became a highly expensive imperial palace for the public. ${ }^{38} \mathrm{By}$ the same token, architecture and sculp-

34 Fittschen, 1992; above n. 32.

35 Ringstone, London Bitish Museum 1385: LIMC 6, 1992, 391 s.v. Medeia no. 32 pl. 198 (Schmidt, M.). - Relief, Gorsium: LIMC 6, 1992, 392 s.v. Medeia no. 33 pl. 198 (Schmidt, M.). - The murder appears much more often in the art of the fourth century BCE. (LIMC 6, 1992, 391-392 s.v. Medeia (Schmidt, M.), possibly due to the funerary use of these images.

36 It is revealing that Medea's furor is explicitly highlighted by the presence of Oistros, the personification of furor, in a third century (?) mosaic from Torre del Palma: Muth, 1998, 260; 446448 pl. 39; $\operatorname{LIMC}$ 7, 1994, 29 s.v. Oistros no. 3 (Müller-Huber, B.) = LIMC 6, 1992, 391, s.v. Medeia no. 33 a (Schmidt, M.).

37 A statue of Medea is recorded in the thermae of Antioch at the Orontes: Manderscheid, 1981, 100 no. 262, but we do not know what exactly was depicted. Infanticide (Athamas-Learchos) was possibly also represented in thermae at Ephesos: Manderscheid, 1981, 87 no. 166.

38 Zanker, 1991, 46; Andreae, 1993, 130; DeLaine, 1997, 79-80. - Their location was near the horti Asiniani, thus relating public baths with the luxury of such horti, cf. La Rocca, 1998, 205207 (for horti as evidence for the spread of luxury to the city); 236-239, and below n. 48. 
ture maintained the emperor's power, by providing spectacular visual experiences and luxurious leisure objects, thus adding to his prestige. ${ }^{39}$

Further, in Caracalla's baths colossality was a leitmotif. These were the largest thermae (and almost the largest piece of public architecture) in Rome. ${ }^{40}$ In addition to the Achilles group, more colossal statues dominated their largest central room, the frigidarium: the 'Hercules Farnese' (fig. 1) and the 'Hercules Caserta' (ht. $3.17 \mathrm{~m}$ ), another crowned Hercules, a gilded colossal Aesculapius and an unidentified male figure. ${ }^{41}$ The exact findspots of the other colossal sculptures are unclear. ${ }^{42}$ Hence, the Baths of Caracalla were not only the thermae of Rome with the greatest number of statues on display (there were around 110 niches for statues), but also those containing the largest statues, with the spectacular frigidarium as the 'centre of colossi'. Indeed, this connected them with the imperial palace on the Palatine. ${ }^{43}$ Games with colossal size also played a role in other features of the baths' sculptural design. The four central columns of the frigidarium were crowned with elaborate figure-capitals (ht. 1.10-1.20 m). One of them replicated the figure of the 'Farnese Hercules' in relief (ht. ca. $0.80 \mathrm{~m}$; fig. 3). ${ }^{44}$ What one saw as a colossal statue on the ground emerged as part of a capital high above (and thus appeared small). It seems that confusing the eye and ex-

39 DeLaine, 1997, 83-84; 207-224; cf. Marvin, 1983, 380-381. - During the second century CE, colossal single statues also appear in thermae outside of Rome, for instance: Gregarek, 1999, 232 no. D134 (Perge).

40 DeLaine, 1997, 46 n. 2; 60-61; 242.

41 'Hercules Farnese', Naples, Museo Nazionale 6001: Vermeule, 1977, 109 no. 1; Manderscheid, 1981, 74 no. 51 pl. 17; Marvin, 1983, 355-357 fig. 1-2; Krull, 1985, 10-22 no. 1 pl. 1-4; Di Mino, 1991, 11 fig. 3; DeLaine, 1997, 80 fig. 47; 266 no. 1. - 'Hercules Caserta', Caserta, Palazzo Reale: Vermeule, 1977, 113 no. 23; Manderscheid, 1981, 74 no. 52; Marvin, 1983, 357 fig. 3; Krull, 1985, 191-197 no. 92 pl. 9; DeLaine, 1997, 266 no. 2. - Head of Aesculapius (gilded), Rome, Museo Nazionale 11614: Vermeule, 1977, 110-111 no. 11; Manderscheid, 1981, 73 no. 46 pl. 16; Di Mino, 1991, $82-83$ no. 12; DeLaine, 1997, 266 no. 5; Marvin, 1983, 363-364 fig. 12 postulates a colossal statue of Hygieia as pendant. - Head of a male youth, Rome, Museo Nazionale 11615: Vermeule, 1977, 110 no. 10; Manderscheid, 1981, 75 no. 60 pl. 18; Marvin, 1983, 364-365 fig. 14-15; Di Mino, 1991, 80-81 no. 11; DeLaine, 1997, 266 no. 6. - Crowned Hercules, lost: Gasparri, 1983-1984, 139 n. 55; DeLaine, 1997, 27.

42 Nude male figure, Naples, Museo Nazionale 6000: Marvin, 1983, 372 pl. 53 fig. 26-27; DeLaine, 1997, 267 no. 18. - Athena, Naples, Museo Nazionale 6319: Vermeule, 1977, 110 no. 4C; Marvin, 1983, 372 pl. 53 fig. 25; DeLaine, 1997, 266 no. 17. - Hand with cup, lost: Marvin, 1983, 366; DeLaine, 1997, 267 no. 21. - Jenewein, 1985, has identified fragments of further colossal statues.

43 Cf. above n. 14.

44 Von Mercklin, 1962, 158-160 no. 385 a-d Abb. 751-758; DeLaine, 1997, 71 fig. 43; Piranomonte, 1998, 7 fig. 5; 10 fig. 9. - Capital with Hercules: von Mercklin, 1962, 158-159 no. 385 a Abb. 751-753; Krull, 1985, 190 no. 91; DeLaine, 1997, 81 fig. 48; Piranomonte, 1998, 38 fig. 42. 
ploring visual experiences was a main purpose of the baths' design. ${ }^{45}$ By the same token, the viewer would be invited to admire the achievements of the sculptors. The colossal 'Hercules Farnese' in the frigidarium (fig. 1) has the name of Glykon inscribed, the Athenian sculptor of the marble copy. Further motivation to investigate this statue as an aesthetic object was provided by the fact that another very similar, though not identical statue, the 'Hercules Caserta', stood in the pendant intercolumniation. Would a viewer have looked for differences? ${ }^{46}$ In addition, gilded statues appeared beside marble and/or colored ones. The 'Farnese Bull' in the palaestra further contributed to such effects (fig. 4). ${ }^{47}$ First, it was a copy of a model, which had itself been on display in Rome since the first century BCE - an invitation to compare original and copy, both of which were carved sensationally from a single piece of stone. ${ }^{48}$ Second, standing in front of this 'massif in marble', one would not only appreciate the colossal statues, but also the small relief figures and plants on the group's marble base, which were additions made by the imperial sculptor. ${ }^{49}$ The diminutive size of these figures, the normal human size of the viewer, and the bigger scale of the mythological figures above asked to be set in relation..$^{50}$ One of the small figures is a young shepherd, seated (fig. 7)..$^{51}$ Amazed by what he is seeing above, he has raised his head, with his mouth open. His dog is jumping up nervously. ${ }^{52}$ It is the colossal size of the statues and the liveliness of the main scene which is explicitly commented here. The real viewer's amazement is anticipated by (as well as being

45 The portrait-statue of a physically deformed dwarf (restored ht. around $1.00 \mathrm{~m}$ ) in Rome, Villa Albani 964 (Bol, 1989, pl. 126-129; Stemmer, 1988, 43 no. D10 [S. Potthoff]), was also found in Caracalla's baths (I owe this reference to A. Grüner). Such an unconventional, small statue of a hunchback (an imperial entertainer?, certainly not Aesopos, as originally supposed) obviously added to the game of size- (and body-) comparison in an almost macabre manner as an additional demonstration of imperial luxury provision, cf. Hist.Aug. Alex. Sev. 34.2-4; Garland, 1995, 48-58. I plan to discuss this figure and its context elsewhere (see above n. 22).

46 Marvin, 1983, 356-357; cf. for pendants in sculpture: Bartman, 1988.

47 Two letters inscribed on the Dirke group seem to be modern rather than an abbreviated artist's signature: Kunze, 1998, 24.

48 Cf. Kunze, 1998, 42. - Plin. NH 36.33-34 for the model of the group in Asinius Pollio's monumenta. If the statues of this collection from the late second century stood in the horti Asiniani, owned by Pollio's family, which were close to Caracalla's baths (cf. Haselberger, 2002, 142; La Rocca, 1998, 236-274, but based on a first century BCE date of the preserved group), then original and copy were, indeed, set up near one another. This would also define the baths as successors of the horti.

49 La Rocca, 1998, 240 fig. 46-49; Kunze, 1998, 60-69 esp. 64-68 (partly contra Andreae, 1993, 119-120).

50 For figures of different sizes in one sculpture cf. Kunze, 1998, 67.

51 La Rocca, 1998, 240 fig. 42-45; Kunze, 1998, pl. 15 c.

52 Partly restored; cf. Apul. Met. 2.4 about the "barking" dogs of a statue of Diana. - For the dog as part of the Dirke group's composition: Andreae, 1993, 119. 
represented in) the smaller marble viewers on the base. The 'internal viewer' draws the real viewer into the scene, which would otherwise be distanced by its colossal size. ${ }^{53}$ The statue group aimed at being appreciated as a kind of a game, with multiple and intense visual experiences. ${ }^{54}$

In approaching the narrative contents of the colossal groups, one must bear in mind that, ever since the early imperial period, the sculptural design of Roman baths reminded visitors of the opera nobilia of Greek art, and of the thermae as places of physical training, health and happy life, evoking ideals of paideia, virtus or luxury. ${ }^{55}$ Mythological statue groups could well be erected in baths, though, as far as we know, not those of colossal proportions. ${ }^{56}$ Thus, sculptures in baths represented either normative exempla of classical culture, or an imaginary world of fantasy. The same was true of statues in villae and horti. Of course, exemplarity was the credo of programmatic sculptures adorning imperial monuments. ${ }^{57}$ While the Dioscuroi, Hercules and Antaios (fig. 2) or the (just) punishment of Dirke (fig. 4), as well as other conventional sculptures in the baths of Caracalla - from Hercules (fig. 1) to Discoboloi - can still be understood in these terms, Medea (fig. 8-9) and Achilles (fig. 5-6) represent something different: human furor leading to the violation of the accepted norms of pietas. And it is this violation (and not its punishment, or a distanced 'Gegenwelt') which is staged. Of course, no one would have taken these images as positive exempla. Furthermore, they cannot be compared to similar images in the private funerary sphere, where they had a different function. Rather, it appears that, in the public sphere, new standards were introduced for choice of subject matter. Exemplarity was no longer the main point. But what was the new appeal of these images? First, one can think of Plutarch's words regarding paintings of Medea and other murderers: what he admires is "not the action (praxis) which is the subject of the imitation, but the art (techne)." (Mor. 18B). The appeal of the statue groups would have been on an aesthetic, rather than on a didactic and paradigmatic level. Another explanation is

53 Zanker, 1991, 43-44.

54 Marvin, 1983, 380.

55 Manderscheid, 1981; Marvin, 1983, 377-380; Neudecker, 1985.

56 Unfortunately, we lack records from Rome (cf. Manderscheid, 1981, 30-46 fig. 9) and in detail, cf. for instance: Manderscheid, 1981, 87 no. 164-168 (Ephesos); 99 no. 250-251 (Aphrodisias); 100 no. 262 (Antioch); 100 no. 263-264 (Apameia); 105 no. 303 (Leptis Magna); 123-124 no. 489-497 (Lambaesis); Gregraek, 1999, 42 Abb. 5; 184 no. B30 (Samos); Goethert, 2000 (Trier).

57 See, for instance, the mythological groups in the Forum Augustum (above n. 7), cf. Himmelmann, 1995, 12-13, who maintains the difference between such statue groups and Classical or Hellenistic examples. - For villas: Neudecker, 1988. 
indicated by an imperial epigram of the Anthologia Graeca (16.142), describing a statue of Medea:

Frenzied you are (mainei) though of stone. The fury (thymos) of your heart

has hollowed your eyes and made them meet to express your anger (cholos).

Yet not even your base shall hold you back, but in your wrath (thymos)

you will leap forward, mad (mainomene) because of your children.

Oh! Who was the artist or sculptor who moulded this,

who sent a stone mad (eis manien) by his skill (eutechnier)?

Although the statue was an immobile Medea in the moment of hesitation before the murder, the author imagines her extreme mania. It is this fantasy which appeals to him, and not the outcome of her terrible decision. Furthermore, he highlights explicitly that this statue is a Medea made of stone. But it is the imagination of the sculpture's (un-)real movement which gives it charm. This double fantasy of (e-)motion sets the pace for the act of viewing. Further, it is not by chance that mainei is the first, while eutechniei is the last word of the epigram. The artist's skill (techne) is the most admirable feature, which enables real furor to appear in the viewer's mind via immovable stone.

Now let us reconsider the colossal groups in the context of these texts. Indeed, the display of artistic skill was an important feature, as their size and complicated workmanship in being carved from a single piece of marble testifies. But earlier sculpture had also been admired because of its artistic qualities. What is significant is that, as we have seen, some of the new groups were the first existing sculptural representations of the myth they depicted (fig. 5-6; 8-9). Sculptors transferred motifs from paintings or reliefs into the round and on a colossal scale, thus creating revolutionary novelties. A comparable technique has been claimed by Nikolaus Himmelmann for late Hellenistic and early imperial mythological groups. ${ }^{58}$ Compared with these examples, what remains new in the late period is the colossal size, combined with the address to a broader public than before. Another impressive feature is the dynamics of composition of these new groups. The punishment of Dirke, Hercules and Antaios, and the slayer of Troilos (fig. 2; 4; 5-6), reveal emotional drama through the physical movements of their protagonists. All of these groups evoke (or copy) Hellenistic models.59 The Hellenistic taste for pathos and movement, which required complicated sculptural responses, obviously underwent a renaissance in the late second and early third century. ${ }^{60}$ This links the statues to phenomena of the Antonine 'Stil-

58 Himmelmann, 1995, 19-21; 23; 28-29; 33-34; 40-42.

59 The punishment of Dirke is a copy; for other groups this has been claimed: Künzl, 1968, 9497 (Achilles-Troilos); Möbius, 1970, 39-47 (Hercules-Antaios).

60 Marvin, 1983, 381; Kunze, 1998, 104-105. 
wandel' in Roman art of the late second century. ${ }^{61} \mathrm{It}$ is interesting to compare the description of a battlefield in Philostratos' Imagines (2.5):

The blood and also the bronze weapons and the purple garments lend a certain glamour (anthos) to the battlefield, and a pleasing (charieis) feature of the painting is the men who have fallen in different postures, and horses running wildly in terror.

This is horror as a form of entertainment. One is reminded of scenes on the column of Marcus Aurelius (fig. 12): of the diverse postures of dead bodies and of the dynamics of murder as illustrated in these reliefs. ${ }^{62}$ Under these auspices, and bearing in mind the growth of interest in expressive movement in different artistic genres, it is plausible that it was related to new aesthetic tastes which demanded complicated compositions, rather than to ideological causes. ${ }^{63}$

The other feature mentioned above, implicit in the Medea epigram, is that the viewer's emotions are aroused by looking at the statue. How does this relate to the statue groups? There can be no doubt that this was relevant for both the 'Farnese Bull' and the Achilles, in that the figures elicit compassion by their dramatic movements (see also Dirke's astonished 'internal viewer'). Emotional engagement is another effect which Hellenistic sculpture aimed at and which is now revitalized. The compelling depiction of emotions is also a typical element of late Antonine 'Stilwandel'.64 The 'Fasanerie Medea' (fig. 8-9), on the other hand, lacks a sense of movement and emotion. Instead, as in the epigram, the statue is impassive. However, compared with earlier images of Medea, the shocking view of the mother in the midst of her furor as murderer of her children challenges the viewer emotionally. The viewer's feelings are confused; one is asked to explore furor as a state of mind on the edges of human passion (and not as a phase in the process of decision-making). A group like Achilles and Troilos (fig. 5-6) could aim at similar effects, as could the 'Farnese Bull' (fig. 4). ${ }^{65}$ Looking at such statues became an emotional experience. This mode of appreciation re-

61 Pelikan, 1965, 29-68; Strong, 1976, 197-217; Jung, 1984, esp. 71-83 (with further bibliography); Pirson, 1997; Scheid - Huet, 2000; see also below n. 64.

62 Pirson, 1997.

63 As an additional visual effect, the use of different colored marbles in a single statue reached its zenith in the Hadrianic and Antonine periods (Gregarek, 1999, 111), and appears also in the baths of Caracalla: Vermeule, 1977, 113 no. 24-25; Marvin, 1983, 369-372 fig. 21-24; Jenewein, 1996; DeLaine, 1997, 266 no. 15-16; Gregarek, 1999, 231-232 no. D130-132; De Nuccio Ungaro, 2002, 299-301 no. 2.

64 For the emotional intensity of Hellenistic sculpture and its reception in Roman art: Schalles, 1985, 85-87; Hölscher, 1987, 20-33; cf. also Stewart, 2003, 513 for Hellenistic rhetoric as related to art. Nevertheless, it has been noticed that, compared to Hellenistic sculpture, the Roman groups are de-emotionalized, Kunze, 1988, 224. - Emotions and 'Stilwandel': Hölscher, 2000, 100-102; see above n. 61.

65 Cf. Marvin, 1983, 381. 
duced the gap between image and viewer, despite the horror and despite the distancing size.

Indeed, the Roman audience must have been very used to such horrific sights even before they saw the first of these groups in Rome. 'Fatal charades' of bloody killings in mythological masks had been common visual experiences for everyone in the arena since the first century CE: even, for instance, being dragged to death like Dirke. ${ }^{66}$ Entertaining as these spectacles were in the flesh, they must also have been entertaining in stone form, at the baths. What is surprising is that, despite the real arena entertainments, such images had been avoided for so long in public imagery, and that they appear at this time. This supports the idea that, in the early imperial period, sculpture on public display was meant to provide visions of joy, exemplarity, and paideia, rather than shocking experiences and pure aesthetics of form. The colossal statue groups are revealing examples of changed ideals of viewing.

Finally, besides engaging the emotions, these groups encouraged physical and intellectual activity on the part of their viewers. The 'Hercules Farnese' (fig. 1) and the 'Hercules Caserta' were set up in the intercolumniations between two rooms of Caracalla's baths so that visitors would walk around the statues in order to see the apples in the hero's right hand: without them, the situation in which Hercules was depicted remained unclear. This was part of Lysippos' original fourth century conception of the statue, but was played out again in the Roman context. ${ }^{67}$ We do not know how the Achilles-Troilos was positioned, but this statue, too, needed to be viewed from more than one side, as we have seen above (fig. 5-6). For the 'Farnese Bull' (fig. 4) it is clear that it was only by walking around the group that the viewer could understand all the figures fully. In this case the Roman sculptor has added base reliefs, figures like Antiope and ornamentation like a lyre or a cista mystica, to provide more narrative motifs in different vistas. ${ }^{68}$ Thus, the sculptures offered diverse visual experiences. As far as intellectual activity was concerned, the groups invited the knowledgeable viewer to recognize the myth and to re-imagine the narrative. None the less, it was due to the narrative potential of some of these multi-figured groups (in contrast to non-narrative single statues) that what was depicted was easy to recognize, even without educated knowledge: brutal murders or fights. On the other hand, unusual iconographies, previously unknown in sculpture, could provide a

66 Coleman, 1990, 60-73; Wistrand, 1992; Morales, 1996, 198-199; Zanker - Ewald, 2004, 38.

67 DeLaine, 1997, 75-80; for the original concept of the late fourth century statue: Krull, 1985, 314-315; Cain, 2002.

68 Kunze, 1998, 60-69. - Changing perspectives were also typical features of Hellenistic sculpture: Schalles, 1985, 89-96; Kunze, 2002, 39-58 (with further bibliography). 
starting point for very educated discussions. The theme depicted and artist's skill might inspire further debates. These different possible levels of interpretation reflect well the broad audience in public spaces like the baths: from the emperor himself to simple veterans (Hist.Ang. Hadr. 17.6-7) and to the educated elite, who might discuss Ennius while bathing (Gell. 3.1). The new sculptures focused upon inspiring appreciation, entertainment and wonder on different levels.

All in all, in the late second and early third century, colossal mythological statue groups were a new phenomenon in Rome's public sphere. They reflect a change in public sculpture, in that they did not focus upon exemplarity, but, through their unusual iconographies, they invited the viewer to explore extreme sides of human life, previously unknown in sculpture - to say nothing of their colossal size. They demanded aesthetic appreciation, but also catered for an uneducated understanding. They demanded active viewers. Their rhetoric was a rhetoric of superlatives, arousing shock and providing entertainment by formal features. They were games with the emotions, by playing on the sense of both distance from and intimacy with their audience. ${ }^{69}$ By means of these sculptures, the baths of Rome became imperial palaces for the plebs (by featuring colossi) and arenas in stone (by staging scenes of horror). As benefactor, the emperor established his role as a powerful provider of luxury. The new groups were an effective way of indicating social distinction and achieving social integration through mass entertainment.

The rhetoric of these new sculptures can indeed be related to phenomena of contemporary literature and oral performance, that is, to phenomena of the Second Sophistic. Here, I can only sketch some suggestions as propositions for further debate. Three categories of comparison will be touched on: the choice of themes, rhetorical techniques, and the competition between visual and literary arts as explored in literary ekphraseis.

Firstly the themes: since the second century, a growing fascination with the description of horror and furor in Roman literature ${ }^{70}$ was combined with a particular interest in the presentation of gruesome and horrific scenes: ${ }^{71}$ for instance in Philostratos' painting of Phorbas, who cuts off his opponent's heads and leaves "some ... withered and others fresh, while others have shrunken to bare skulls"(Im. 2.19.2), or in the same author's horrible images of the dead children of Hercules (2.23.2), or of Abderos' body parts (2.25.1). One could also consider Achilles Tatios' bloody painting of Prometheus with the eagle (Leucippe and Clito-

69 Marvin, 1983, 382-383.

70 Hershkowitz, 1998.

71 Steinmetz, 1982, 249-250; Anderson, 1993, 145. 
phon 3.8.1-2). ${ }^{72}$ Descriptions of such horrific images served as owvertures in texts, like the 'blood-and-corpses' scene described at the beginning of Heliodoros' Aithiopica. Apuleius in his Golden Ass explores them ironically. ${ }^{73}$ Obviously, this is not intended to create suspense, but rather represents an aesthetics of horror. ${ }^{74}$ The same could be said about Medea or Achilles in the groups discussed above. The appeal of horror, long familiar from arena spectacles, now made its way into public entertainment - and into the visual culture. Further, it is well known that the exploration of emotions was a focal theme of the same novels which were also full of the horrific scenes mentioned above. ${ }^{75}$ While their protagonists' lovetroubles aimed at creating a sense of intimacy with the reader, the 'aesthetics of horror' evoked fascination on another, equally emotional level. This is also true for some of Philostratos' Imagines, for instance, when Hercules' mania is explored in detail (2.23.4), or when the fictional viewer is looking at a love-story in a boar hunt, overwhelmed by his own desire (1.28). ${ }^{76}$ The new statue groups and the literature of the late second and early third century both had as their common purpose the evocation of psychological compassion. This was achieved by drawing the audience emotionally into the situation depicted/described, by choosing horrific or emotionally loaded themes. As far as rhetorical techniques are concerned, further parallels between oral and visual arts can be observed. Thomas Schmitz has suggested that the techniques of sophistic orators to evoke sympathy can be construed as a result of their concern with establishing social distinction. ${ }^{77}$ Sophists played a balancing game: on the one hand, the ideas of paideia were open to all, while on the other, elite distinction was demonstrated by the use of psychagogic strategies. A comparable game of distance and proximity is played out in the colossal groups. In this case, the audience is attracted by spectacular artistic skill and emotionally shocking scenes, thus bridging the gap established by the statues' colossal size, and by the fact that the emperor was the benefactor. Thus, the groups functioned both to monopolize the discourse of entertainment and to negotiate social distinction: social distinction between the emperor and the plebs, and between pepaideumenoi, who would understand the sculptures completely, and those viewers shocked only by theme and size. ${ }^{78}$ Further, these sculptures would inspire discussion on different levels: from Medea's furor to the iconography of

Cf. Bartsch, 1989, 57-58.

Apul. Met. 1.13.4-6; 4.10.3-11.3.

74 Earlier debates about such horrific scenes in art: Morales, 1996.

75 Schmeling, 1996; Swain, 1996, 101-131; Holzberg, 2001.

76 Cf. also Philostr. Im. 2.23.1.

77 Schmitz, 1997, 160-196; cf. Korenjak, 2000, 41-65.

78 Korenjak, 2000, 52-65; cf. the two groups of audience mentioned in Lucianus Dom. 2. 
Achilles' cruel deed - as we know, provoking such discussions was also a goal of the Second Sophistic oratory. ${ }^{79}$

In addition, the prestige of formal elements (in contrast to content) was typical of sophistic oratory. The brilliant rhetorical performances of this period aimed primarily at virtuosity and applause. ${ }^{80}$ This is what we have also observed in the mythological groups - it was less important for the visual arts of the early imperial period, compared with exemplarity of content and the imitation of classical models. It appears that, in this sense, the category of epideixis, which well describes the characteristics of Second Sophistic oratory, could be applied to the groups discussed. ${ }^{81}$ Epideixis as a mode of speech does not aim at evoking decision about content, but rather at activating the audience's judgment about the speech's rhetorical and artistic quality. Philostratos also calls his descriptions of paintings epideixis (Im. 1 praef.). This perfectly matches the rhetorical technique of the colossal groups. Even though arousing the viewer's amazement and formal appreciation had long been the purposes of Roman idealized sculpture, it is the prominence of such 'epideictic images' and the extent of this interest, which defines the new quality of the colossal statue groups from the later second century CE on. ${ }^{82}$

One literary genre especially invites comparison with such a new rhetoric of statues: literary ekphrasis. ${ }^{83}$ Imaginary descriptions of images are a useful means of gaining an insight into how real images might have been looked at and appreciated in a particular epoch. ${ }^{84}$ The period under investigation here saw the emergence of an autonomous literary genre of ekphraseis of works of art, as in Philostratos' Imagines. ${ }^{85}$ Previously, descriptions of art objects had been found either in short passages of larger literary works, or were mere exercises in the rhetorical

79 Korenjak, 2000, 120-124.

80 Bowersock, 1969, 13; Steinmetz, 1982, 188-192; Russell, 1983; Anderson, 1993, 55-68; Korenjak, 2000, 21-40.

81 Lausberg, 1973, 129-138 \$239-254; Martin, 1974, 177-210; Rüpke, 1997; Korenjak, 2000, 13 14; 23-24; cf. Quint. Inst. 3.4.12-16 and Arist. rh. 1.3 p. 1358b for the definition of this rhetorical genre.

82 Another common technique of the Dirke group and Apuleius is drawing viewers/readers into the depicted/described scene, cf. Slater, 1998, 36-37.

83 Bartsch, 1989, 4-39; Heffernan, 1993; Boehm - Pfotenhauer, 1995; Graf, 1995; Reitz - Egelhaaf, 1997; Zumbo, 1998; Fowler, 2000, 64-85 (= Fowler, 1991), all with further bibliography; see also below n. 86 .

84 Goldhill, 1994. - Cf. for the Geometric period now Giuliani, 2003, 39-46; for Hellenistic Art: Zanker, 2004. - Ekphraseis and Roman Art: Elsner, 1995, 21-48; Amedick, 1998; NoackHilgers, 1999; Elsner, 2000; Newby, 2002a; further bibliography below n. 86; cf. also Altekamp, 1988, for later ekphraseis.

85 Michel, 1974; Anderson, 1986; Beall, 1993; Elsner, 1995, 21-48; Schönberger, 1995; Boeder, 1996, 137-170; Elsner, 2000; Leach, 2000; Abbondanza, 2001, each with further bibliography. 
training. ${ }^{86}$ But ekphraseis have their heyday in this period. ${ }^{87}$ In novels, they could even function as a starting point for the story as in Longos' Daphnis and Chloe or in Achilles Tatios' Clitophon and Leukippe. This emergence of ekphraseis in itself reveals the specific importance of images as media of cultural discourse in high imperial Rome. ${ }^{88}$ Thus, comparing the rhetorical strategies of these descriptions of images with the rhetoric of 'real' imagery should be profitable. It has been observed, for instance, that both the detailed process of viewing images, as described in literature, and the often anti-narrative character of these descriptions, go hand in hand with the growing importance of single attributes, motifs and the decorative detail of collective statue groups, like the punishment of Dirke or the (now descriptive rather than narrative) reliefs on Roman sarcophagi. ${ }^{89}$ This suggests common ways of reading images and ekphraseis. Furthermore, following John Winkler's Auctor \& Actor, Shadi Bartsch has analyzed the rhetorical functions of ekphraseis in novels. ${ }^{90}$ They serve as keys to the narrative, presenting interpretative clues for the developments that follow, and thus stimulating the readers' "hermeneutic activities" through their participation in a game of interpretation. ${ }^{11}$ But often, how they should be understood remains ambiguous. Thus, they undermine the idea of a single, correct meaning for an image. Philostratos also aims at teaching readers "to interpret paintings and to appreciate what is esteemed in them" (Im. 1 proem. 3) - but this appreciation is multiple and never focuses upon a precise message beyond the narrative itself. Thus, comparable to the statue groups, ekphraseis evoke a process of emotional and active viewing, which result in a very personal experience for each reader. ${ }^{92}$ And, like the groups, they allow the audience to explore their (visual, emotional and aesthetic) experiences.

A final, possibly more direct, relation between literary ekphraseis and colossal mythological statue groups can be suggested here. Again, Philostratos' Imagines are the starting point for the argument. Since the author/narrator/viewer deals exclusively with paintings, it is understandable that he argues for the preeminence of the art of painting (zographia) over the plastic art (plastike, Im. 1 praef. 12). Painting "permits the observer to recognize the look, now of a man who is

86 For rhetorical exercises (progymnasmata): Kennedy, 2003.

87 Bartsch, 1989; Slater, 1998, with further bibliography.

88 Graf, 1995, 152-153.

89 Zanker, 1991, 43-44; Kunze, 1998, 68; Zanker - Ewald, 2004, 253; cf. also Apuleius' group of Diana with Aktaion (met. 2.4): Slater, 1998. - For the categories 'descriptive' and 'narrative' cf. Giuliani, 2003.

90 Bartsch, 1989; Winkler, 1985; cf. also Slater, 1998.

91 Bartsch, 1989 passim; cf. Winkler, 1985, 11-14; Slater, 1998.

92 For instance, in contrast to Vergil's message-focused ekphraseis: Eigler, 1998; Österberg, 1999. 
mad, now of a man who is sorrowing or rejoicing." Sculpture, on the other hand, is the least effective of the imitative arts, as far as such emotions are concerned. As Letizia Abbondanza has argued, the Imagines were obviously embedded in a discourse about the competing qualities of the different artistic genres. ${ }^{93} \mathrm{Ar}$ chaeological evidence contributes to this idea. For instance, in Herodes Atticus' villa in Luku, Achilles and Penthesilea were set up as a marble sculpture in a room, along with a colored mosaic depicting the same situation with the same iconography. Of course, this installation invited the viewer to compare both genres. ${ }^{94}$ If such a discourse was indeed of growing importance in this period, ${ }^{95}$ establishing ekphraseis as an autonomous genre of literature would not be the only result; the emergence of the new colossal mythological groups in the Roman public sphere could also be seen as an attempt to explore new effects and ways of convincing the viewer of a valuable (and prestigious) source of visual entertainment. It is noteworthy in particular that the expressions of emotion and feeling, which Philostratos denies to the plastic arts, are exactly what is present in the new colossal statue groups. And it is movement (motus) which is explored by some of the groups, a quality absent from paintings, as Apuleius says (Apol. 14). The statue groups would thus aim at proving the particular achievements of sculpture, and establishing their high quality compared with paintings. ${ }^{96}$

It remains open as to whether this competition was direct, and if the imperial court, to which Philostratos was related and which was responsible for at least some of the statue groups, played an active role in encouraging it. What I have tried to demonstrate is that in an atmosphere of competition between the arts, the emergence of colossal statue groups in the late second and early their century CE not only signifies a search for new kinds of visual rhetoric by creating 'epideictic images' and new opportunities of visual amazement in sculpture by an aesthetics of horror which played on the emotions. Also, on a social level, they reveal the interest of the emperor in controlling visual culture, maintaining distinction by granting luxury, and gaining prestige by providing new forms of entertainment. This interpretation relates the statues to aesthetic and social phenomena of the Second Sophistic. It appears that exploring brilliant effects and breaking 'classical' standards by references to Hellenistic tastes were important

93 Abbondanza, 2001, 121-133.

94 Tobin, 1997, 353 no. 12; Spyropoulos, 2001, 129-130 pl. 5-9; cf. Galli, 2002, 205; above n. 18; it is still open as to whether there was also a copy of the Pasquino group: Tobin, 1997, 344 no. $1 ; 353$ ad no. 12.

95 Cf. also D.H. Orat.Vett. 12; Klauck - Bäbler, 2000.

96 Cf. Slater, 1998, 41-44. - Other phenomena of the Antonine 'Stilwandel' need further investigation in this sense, too. 
factors of change in the visual culture of Rome in the late second and early third century CE, rather than stemming purely from an interest in the demonstration of paideia as a knowledge of classical Greek culture.

\section{Acknowledgements:}

I thank the organizers of the Heidelberg conference, especially Barbara Borg, for inviting me to present this paper. Thanks go to Reinhard Förtsch and the Forschungsarchiv für Antike Plastik for making possible photographic documentation together with the DFG, to Gisela Fittschen-Badura for her photographic skill, to Martin Miller and Andreas Dobler for hospitality and assistance in Schloss Fasanerie, to Sylvia Diebner and Luciano Pedicini for providing photographs, to Peter von Möllendorff for helpful suggestions and to Kris Giannotta as well as to Frieda Klotz for their correction of my English. Nevertheless, any mistakes remain my responsibility. 


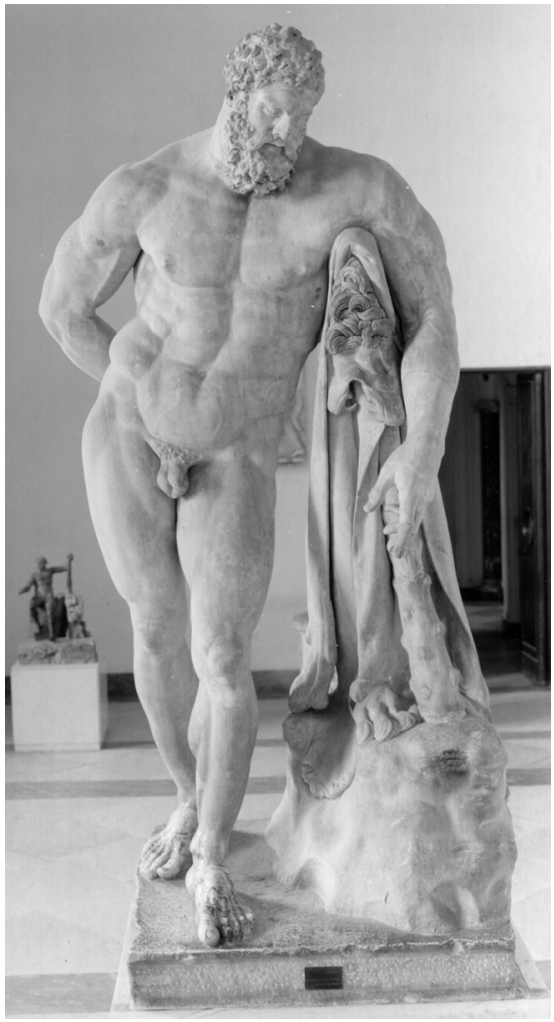

1 'Hercules Farnese'. Marble, early third century CE; copy after late fourth century BCE original. Naples, Museo Nazionale 6001.

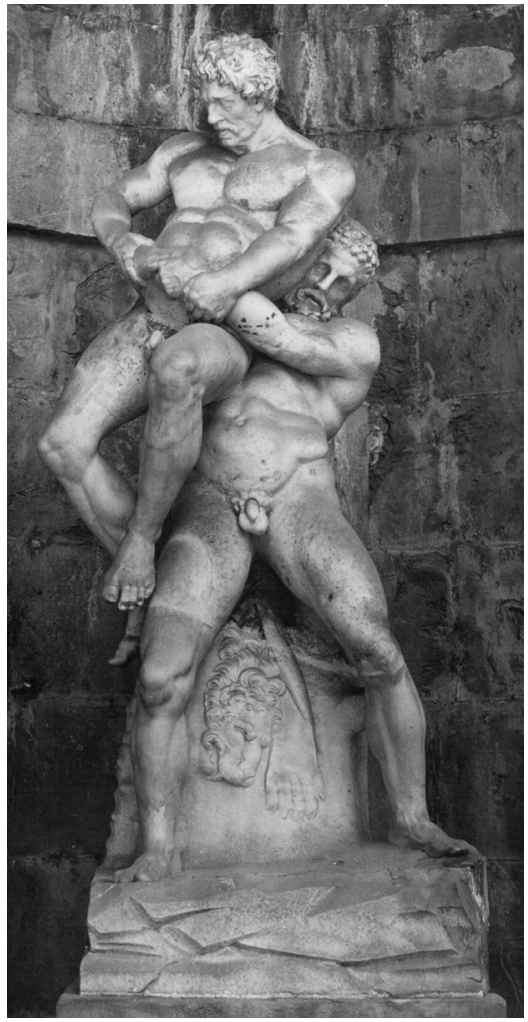

2 Hercules and Antaios. Marble, around 200 CE. Florenz, Palazzo Pitti.

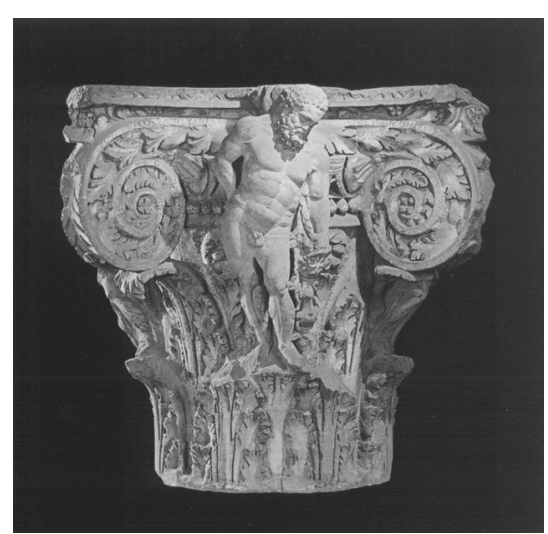

3 Capital from the Baths of Caracalla. Marble, early third century CE Rome. 


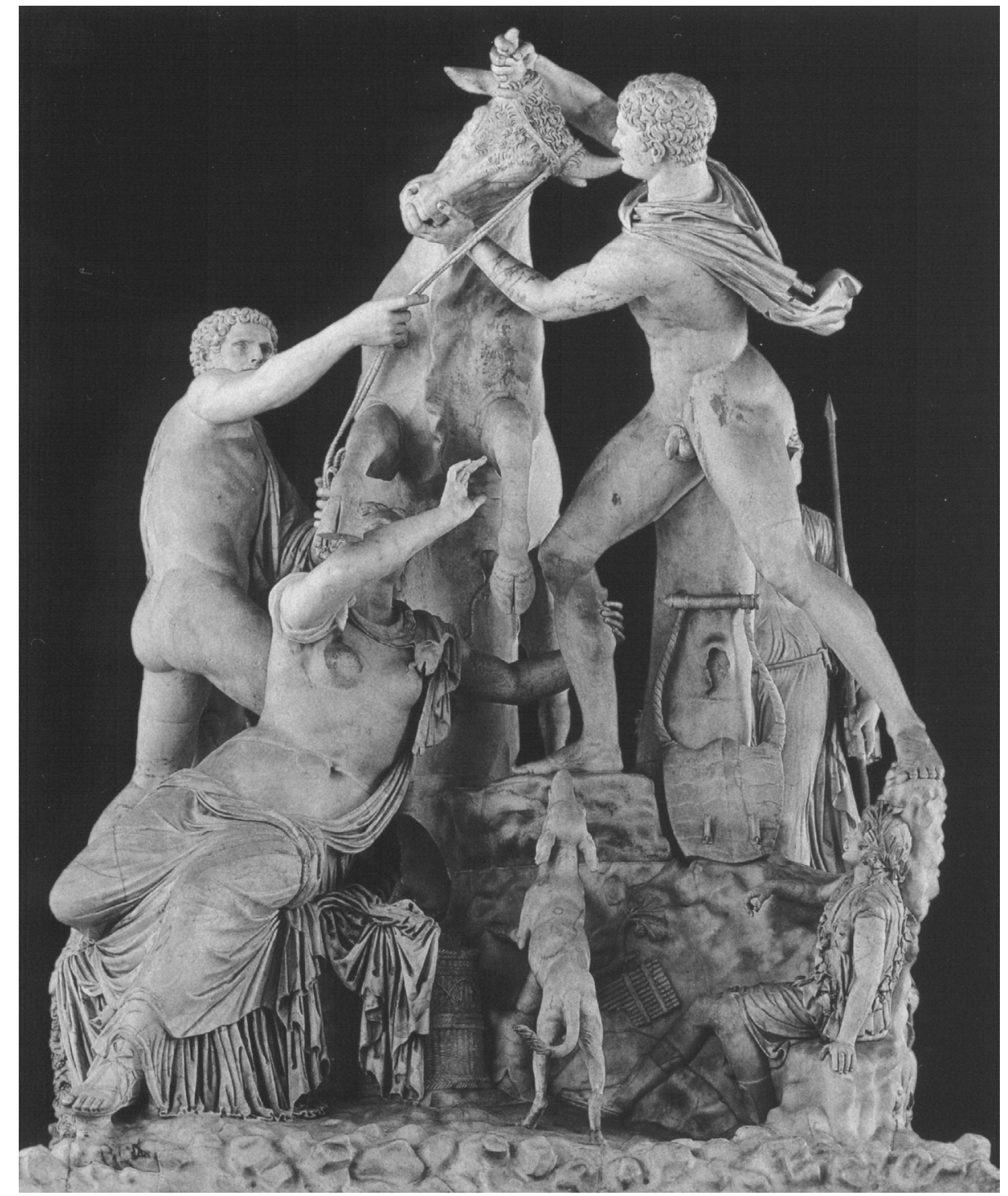

4 'Farnese Bull'. Marble, early third century CE, copy after Hellenistic original. 


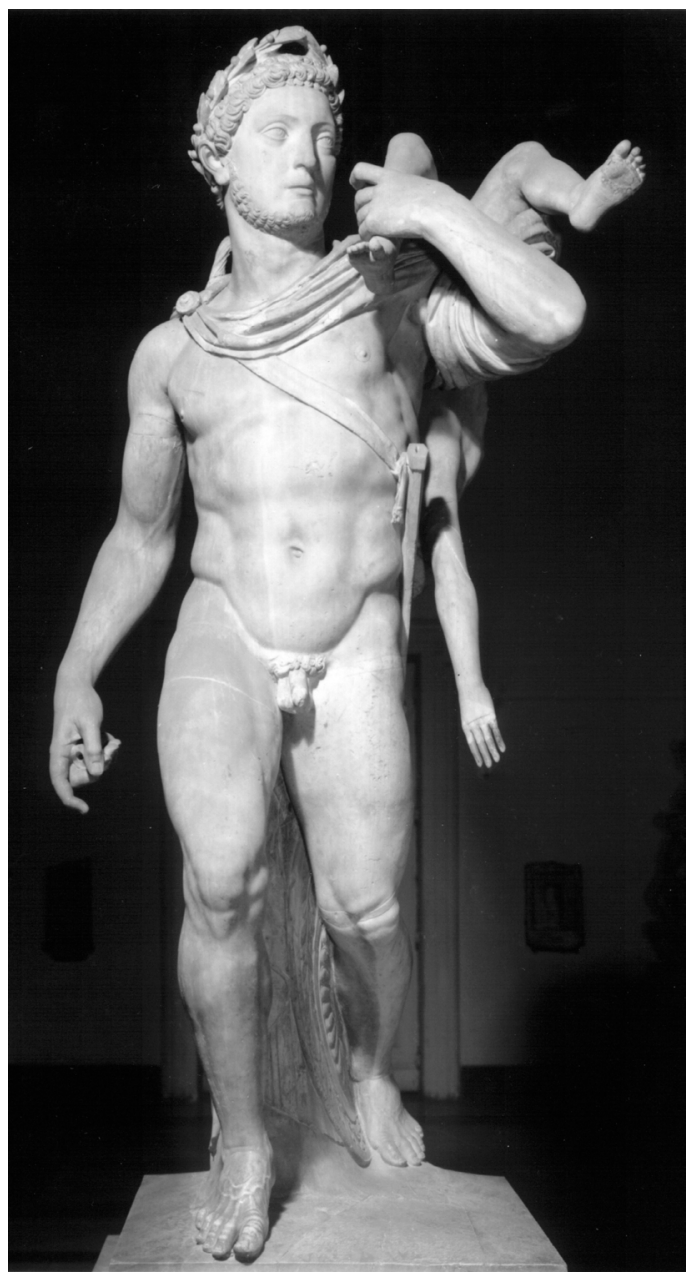

5 Achilles hurling Troilos (?). Marble, early third century CE. Naples, Museo Nazionale 5999.

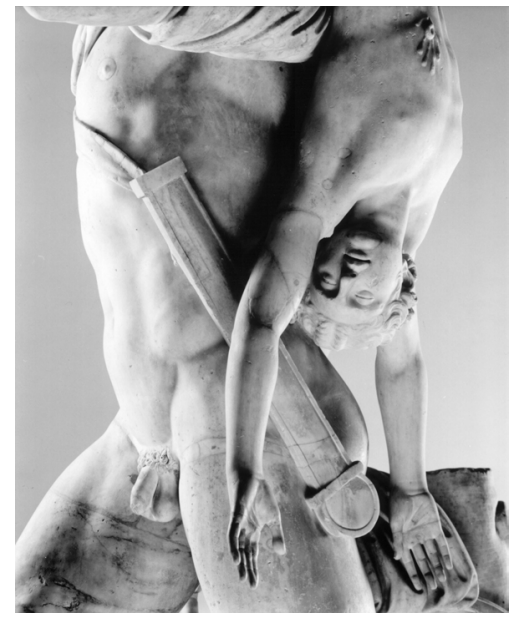

6 Achilles hurling Troilos (?), detail.

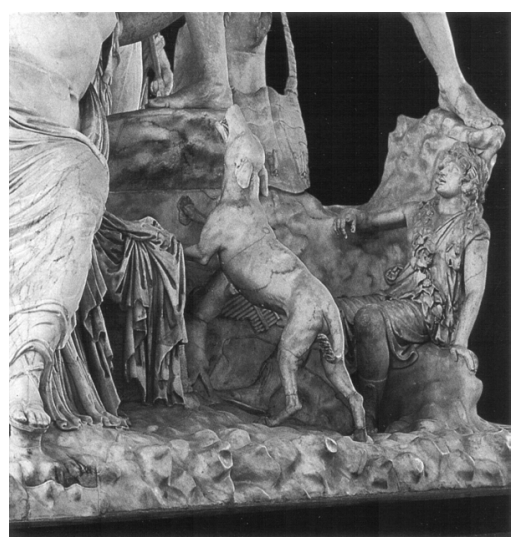

7 Basis of the 'Farnese Bull' (fig. 4), detail. 

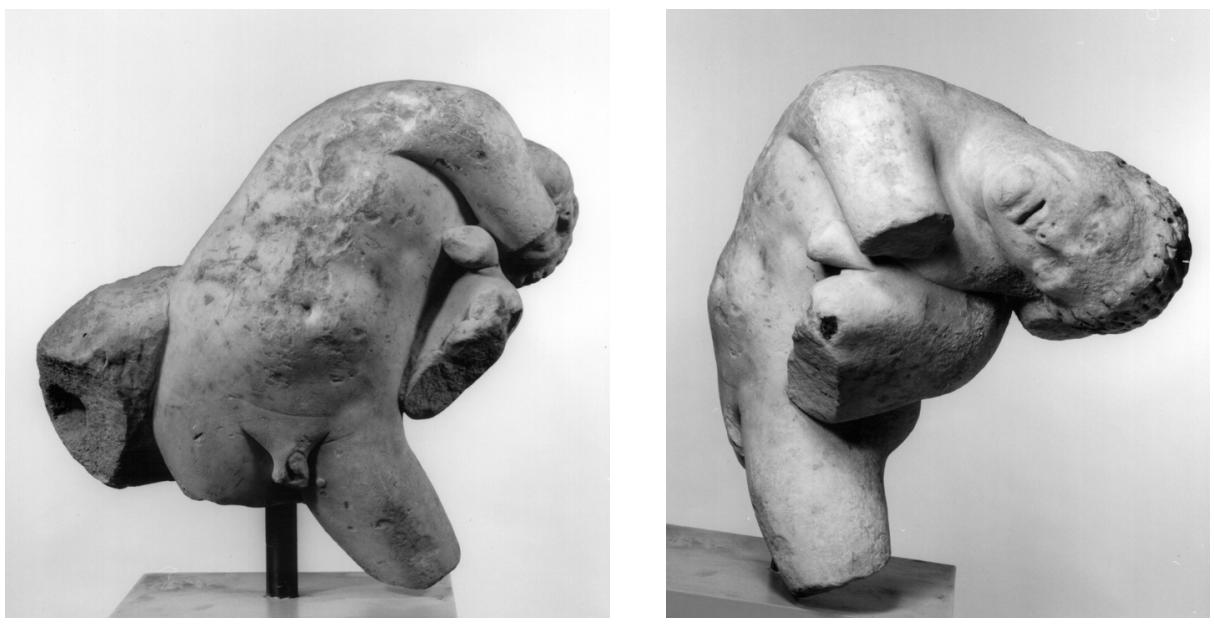

8-9 Medea with one of her children (?), fragment of a group. Marble, late second or early third century CE. Eichenzell, Schloss Fasanerie AMa 41.

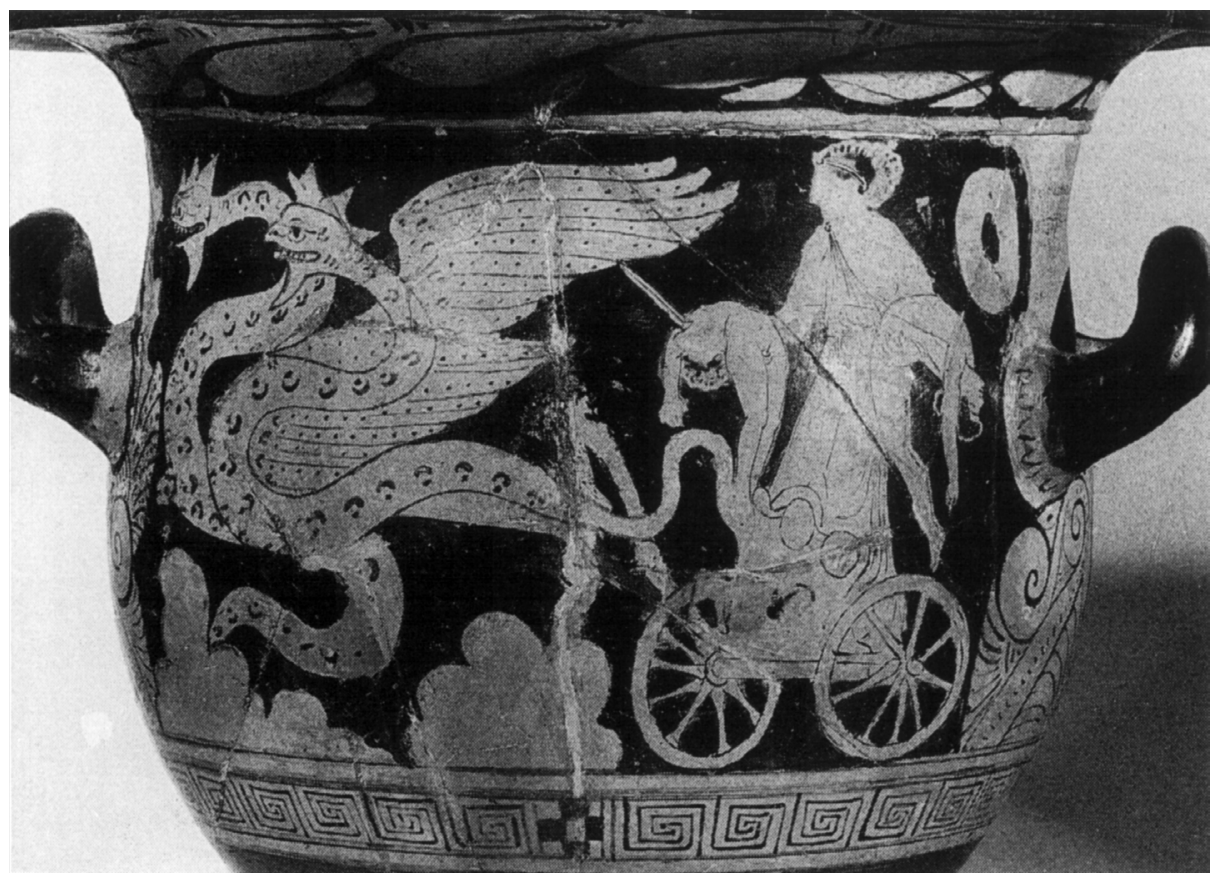

10 Medea with her children. Faliscan bell-krater, fourth century BCE. St. Petersburg. 


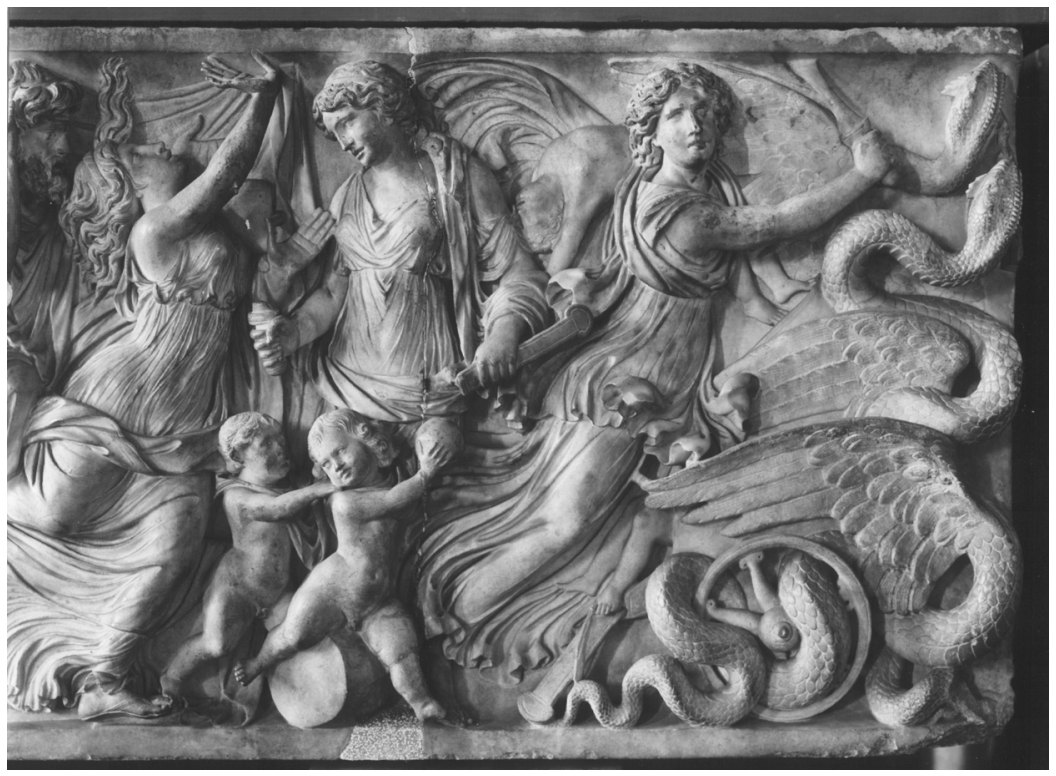

11 Medea before the murder and fleeing with her children. Marble sarcophagus, second century CE. Berlin, Antikensammlung Sk 843 b.

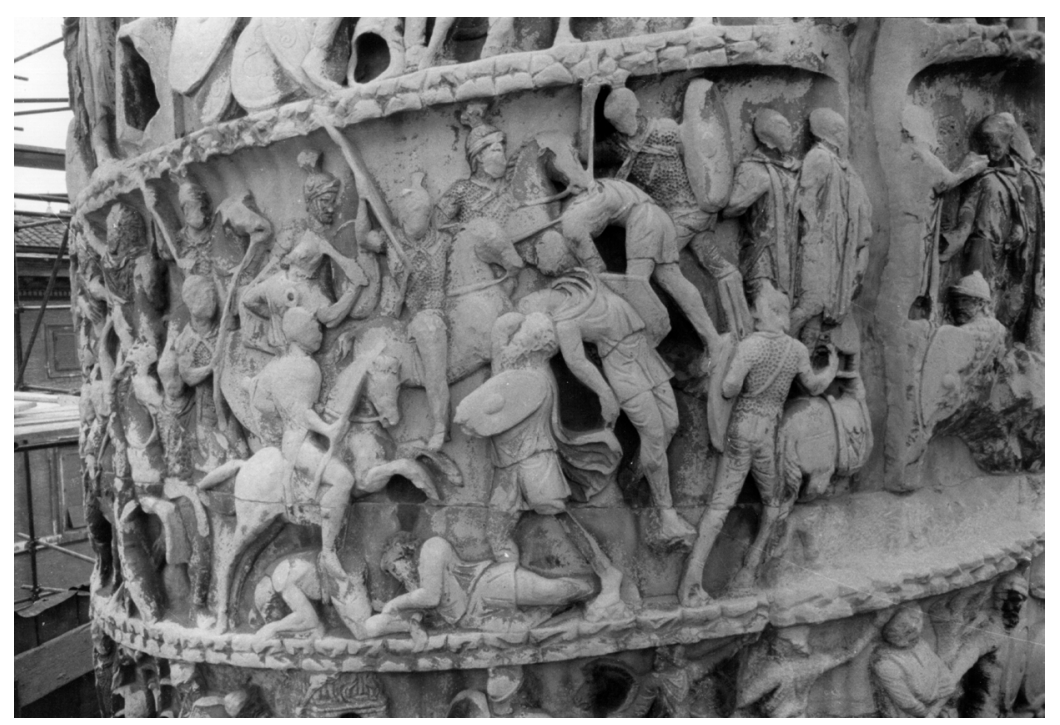

12 Column of Marcus Aurelius, scene 50. Rome. 
Bibliography

Abbondanza, L. 2001: Immagini della phantasia, in: $M D A I(R)$ 108, 111-134.

Altekamp, S. 1988: Zu den Statuenbeschreibungen des Kallistratos, in: Boreas 11, 77-154.

Amedick, R. 1998: Achilleus auf Skyros, in: Koch, G. (ed.), Akten des Symposions "125 Jahre Sarkophag-Corpus", Mainz 1998, 52-60.

Anderson, G. 1986: Philostratus. Biography and Belles Lettres in the Third Century A. D., London.

Anderson, G. 1990: The Second Sophistic: Some Problems of Perspective, in: Russell, D. A. (ed.), Antonine Literature, Oxford 1990.

Anderson, G. 1993: The Second Sophistic. A Cultural Phenomenon in the Roman Empire, London.

Andreae, B. 1993: Auftraggeber und Bedeutung der Dirke-Gruppe, in: JDAI 100, $107-$ 131.

Andreae, B. 1999: Odysseus. Mythos und Erinnerung, exhibition catalogue Munich, Mainz.

Andreae, B. 2001: Skulptur des Hellenismus, München.

Arcellaschi, A. 1990: Médée dans le théâtre latin d’Ennius à Sénèque, Roma.

Arcellaschi, A. 1996: La violence dans la Médée de Sénèque, in: Pallas 45, 183-190.

Arndt, P. et al. (ed.), 1893-1939: Photographische Einzelaufnabmen antiker Sculpturen, München.

Bartman, E. 1988: Decor et duplicatio. Pendants in Roman sculptural display, in: $A J A$ 92, 211-225.

Bartsch, S. 1989: Decoding the Ancient Novel. The Reader and the Role of Description in Heliodoros and Achilles Tatius, Princeton.

Baumer, L. 2001: Praeterea typos tibi mando - Klassische Weihreliefs im römischen Kontext, in: Reusser, 2001, 85-94.

Beall, S.M. 1993: Word-painting in the 'Imagines' of the Elder Philostratos, in: Hermes 121, 350-363.

Belli Pasqua, R. 1995: Sculture di età romana in basalto, Roma.

Bergmann, M. 1993: Der Koloss Neros, die Domus Aurea und der Mentalitätswandel im Rom der frühen Kaiserzeit, Trierer Winckelmannsprogramme 13, Mainz.

Bergmann, M. 1998: Die Strablen der Herrscher, Mainz.

Boeder, M. 1996: Visa et vox. Sprache und Bild in der spätantiken Literatur, Frankfurt a. M..

Boehm, G. - Pfotenhauer, H. (eds.) 1995: Beschreibungskunst-Kunstbeschreibung, München.

Bol, P.C. 1972: Die Skulpturen des Schiffsfundes von Antikythera, MDAI(A) Beiheft 2, Berlin.

Bol, R. 1989: 75. Porträt eines Buckligen (sog. Aesop), in: Bol, P.C. (ed.): Forschungen zur Villa Albani. Katalog der antiken Bildwerke 1, Berlin 1989, 227-231. 
Borg, B. - Witschel, C. 2001: Veränderungen im Repräsentationsverhalten der römischen Eliten während des 3. Jhs. n. Chr., in: Alföldy, G. - Panciera, S. (eds.): Inschriftliche Denkmäler als Medien der Selbstdarstellung in der römischen Welt, Stuttgart 2001, 48-120.

Bowersock, G.W. 1969: Greek Sophists in the Roman Empire, Oxford.

Bowie, E.L. 1970: The Greeks and their Past in the Second Sophistic, in: Past and Present 46, 3-41.

Bowie, E.L. 2000: Literature and Sophistic, in: The Cambridge Ancient History, 2nd edition, 11, Cambridge, 898-921.

Cain, H.-U. 2002: Der Herakles Farnese - ein müder Heros?, in: Corbineau-Hoffmann, A. - Nicklas, P. (eds.): Körper / Sprache. Ausdrucksformen der Leiblichkeit in Kunst und Wissenschaft, Hildesheim 2002, 33-61.

Cambitoglou, A. - Chamay, J. (eds.) 1997: Céramique de la grande Grèce, exhibition catalogue Genève, Genève.

Cancik, H. 1990: Grösse und Kolossalität als religiöse und ästhetische Kategorien, in: VisRel 7, 51-64.

Cima, M. - La Rocca, E. (eds.) 1986: Le tranquille dimore degli dei. La residenza imperiale degli Horti Lamiani, exhibition catalogue Rome, Venezia.

Cima, M. - La Rocca, E. (eds.) 1998: Horti romani, colloquium Rome, BCAR Supplementi 6, Roma.

Clauss, J. J. et al. (eds.) 1997: Medea, Princeton.

Coleman, K.M. 1990: Fatal Charades. Roman Executions Staged as Mythological Enactments, in: JRS 80, 44-73.

Corti, L. 1998: The Myth of Medea and the Murder of Children, Westport.

Danguillier, C. 2001: Typologische Untersuchungen zur Dichter-und Denkerikonographie in römischen Darstellungen von der mittleren Kaiserzeit bis in die Spätantike, BAR International Series 977, Oxford.

de la Barrera, J.L. - Trillmich, W. 1996: Eine Wiederholung der Aeneas-Gruppe vom Forum Augustum samt ihrer Inschrift in Merida, in: $M D A I(\mathrm{R}) 103,119-138$.

De Nuccio, M. - Ungaro, L. 2002: I marmi colorati dell Roma imperiale, exhibition catalogue Rome, Venezia.

DeLaine, J. 1997: The Baths of Caracalla, Journal of Roman Archaeology. Univ. of Michigan Supplement 25, Portsmouth.

Di Mino, M.R. 1991: Rotunda Diocleziani. Sculture decorative delle terme nel Museo nazionale Romano, exhibition catalogue Rome, Roma.

Eigler, U. 1998: Augusteische Repräsentationskunst als Text?, in: Gymnasium 105, 288305.

Elsner, J. 1995: Art and the Roman Viewer, Cambridge.

Elsner, J. (ed.) 1996: Art and Text in Roman Culture, Cambridge.

Elsner, J. 1998: Imperial Rome and Christian Triumph, Oxford. 
Elsner, J. 2000: Making Myth Visual: The Horae of Philostratus and the Dance of the Text, in: $M D A I(R)$ 107, 253-276.

Ewald, B.C. 1999: Der Philosoph als Leitbild, MDAI(R) Ergänzungsheft 34, Mainz.

Ewald, B.C. 2003: Sarcophagi and Senators: the social history of Roman funerary art and its limits, in: Journal of Roman Archaeology. Univ. of Michigan 16, 561-571.

Fantham, E. 1998: Literarisches Leben im antiken Rom, Stuttgart.

Fischer-Bossert, W. 2001: Der Porträttypus des sog. Plotin. Zur Deutung von Bärten in der römischen Porträtkunst, in: $A A, 137-152$.

Fittschen, K. 1992: Der Tod der Kreusa und der Niobiden. Überlegungen zur Deutung griechischer Mythen auf römischen Sarkophagen, in: SIFC 10, 1046-1059.

Fittschen, K. 1994: Review of: Kreikenboom, 1992, in: Gnomon 66, 612-615.

Fittschen, K. 1999: Prinzenbildnisse antoninischer Zeit, Mainz.

Fittschen, K. - Zanker, P. 1985: Katalog der römischen Porträts in den Capitolinischen Museen und den anderen kommunalen Sammlungen der Stadt Rom, Mainz.

Flashar, H. (ed.) 1979: Le classicisme à Rome, Entrétiens sur l'antiquité classique 25, Genève.

Fowler, D. 1991: Narrate and Describe, in: JRS 81, 25-35.

Fowler, D. 2000: Roman Constructions, Oxford.

Gaggadis-Robin, V. 1994: Jason et Médée sur les sarcophages d'époque impériale, Rome.

Galli, M. 2001: Pepaidoimenoi am Ort des Heiligen, in: Reusser, 2001, 43-70.

Galli, M. 2002: Die Lebenswelt eines Sophisten. Untersuchungen zu den Bauten und Stiftungen des Herodes Atticus, Mainz.

Gallottini, A. 1995: Philippe Thomassin, Antiquarum statuarum urbis Romae liber primus (16101622), in: BA, volume speciale, Rome.

Garland, R. 1995: The Eye of the Beholder, London.

Gasparri, C. 1983-84: Sculture provenienti dalle Terme di Caracalla e di Diocleziano, in: Rivista dell'Istituto Narionale di Archeologia e Storia dell'Arte 6-7, 133-150.

Gentili, B. - Perusino, F. 2000: Medea nella letteratura e nell'arte, Venezia.

Geominy, W. 1984: Die Florentiner Niobiden, Bonn.

Geominy, W. 1999: Zur Komposition der Gruppe „Die Aufforderung zum Tanz“, in: Hellenistische Gruppen. Gedenkschrift für Andreas Linfert, Mainz 1999, 141-155.

Geppert, S. 1996a: Castor und Pollux, München.

Geppert, S. 1996b: Die monumentalen Dioskurengruppen in Rom, in: Antike Plastik 25, München, 121-150.

Giuliani, L. 2003: Bild und Mythos. Geschichte der Bilderzählung in der griechischen Kunst, München.

Goethert, K.-P. 2000: Repliken der 'Florentiner Niobiden' aus den Barbarathermen in Trier, in: Archäologisches Korrespondenzblatt 30, 437-444.

Goldhill, S. 1994: The Naive and Knowing Eye, in: Goldhill, S. - Osborne, R. (eds.): Art and Text in Ancient Greek. Culture, Cambridge 1994, 197-223. 
Goldhill, S. (ed.) 2001: Being Greek under Rome, Cambridge.

Graf, F. 1995: Ekphrasis: Die Entstehung der Gattung in der Antike, in: Boehm - Pfotenhauer, 1995, 143-155.

Graepler, D. (ed.) 2002: Barbarentod und Venuskult. Griechische Skulpturen aus den Gärten Roms, exhibition catalogue, Göttingen.

Gregarek, H. 1999: Untersuchungen zur kaiserzeitlichen Idealplastik in Buntmarmor, in: Kölner Jahrbuch für Vor-und Frühgeschichte 32, 33-284.

Grüner, A. in print: Bildung, öffentlicher Raum und aristokratische Verhaltensnorm im antoninischen Rom, in: Hermes.

Hahn, J. 1989: Der Philosoph und die Gesellschaft, Wiesbaden.

Häuber, R.C. 1991: Horti romani. Die Horti Maecenatis und die Horti Lamiani auf dem Esquilin, Köln.

Hartswick, K.J. 2004: The Gardens of Sallust, Austin.

Haselberger, L. et al. 2002: Mapping Augustan Rome, Journal of Roman Archaeology. Univ. of Michigan Supplement 50, Portsmouth.

Hebert, B.D. 1983: Spätantike Beschreibungen von Kunstwerken. Archäologischer Kommentar zu den Ekphraseis des Libanios und Nikolaos, Graz.

Heffernan, J.A.W. 1993: Museum of Words. The Poetics of Ekphrasis, Chicago.

Hershkowitz, I. 1998: The Madness in Epic. Reading Insanity from Homer to Statius, Oxford.

Himmelmann, N. 1991: Laokoon, in: AK 34, 97-115.

Himmelmann, N. 1995: Sperlonga. Die homerischen Gruppen und ibre Bildquellen, Opladen.

Hölscher, T. 1987: Römische Bildsprache als semantisches System, Abhandlungen der Heidelberger Akademie der Wissenschaften. Philosophisch-historische Klasse Abhandlung 2, Heidelberg.

Hölscher, T. 2000: Die Säule des Marcus Aurelius, in: Scheid - Huet, 2000, 89-105.

Holzberg, N. 2001: Der antike Roman, Düsseldorf/Zürich.

Jenewein, G. 1985: Statuenfragmente aus den Caracallathermen, in: Römische historische Mitteilungen 27, 13-49.

Jenewein, G. 1986: Ein Porträtfragment aus den Caracallathermen, in: BCAR 91, 97-100.

Jenewein, G. 1996: Ein Neos Dionysos, eine Mänade und ein Fragment, in: Blakolmer, F.: Fremde Zeiten. Festschrift für J. Borchardt zum sechzigsten Geburtstag, Wien 1996, 283-290.

Jucker, H. 1950: Vom Verbältnis der Römer zur bildenden Kunst der Griechen, Frankfurt a. M..

Jung, H. 1984: Zur Vorgeschichte des spätantoninischen Stilwandels, in: Marburger Winckelmann-Programm, 59-103.

Kennedy, G.A. 2003: Progymnasmata, Atlanta.

Klauck, H.-J. - Bäbler, B. 2000: Dion von Prusa: Olympische Rede, Darmstadt.

Korenjak, M. 2000: Publikum und Redner. Die Interaktion in der sophistischen Rhetorik der Kaiserzeit, Zetemata 104, München. 
Kreikenbom, D. 1992: Griechische und römische Kolossalporträts bis zum ersten Jh. n. Chr., JDAI Ergänzungsheft 27, Berlin.

Krull, D. 1985: Der Herakles vom Typ Farnese, Frankfurt a.M..

Kunze, C. 1988: Fliehende Niobetochter and Bestrafung der Dirke, in: Marc Aurel und seine Zeit, exhibition catalogue Berlin, Berlin 1988, 220-225.

Kunze, C. 1991: Dall'originale greco alla copia romana, in: Pozzi, 1991, 13-42.

Kunze, C. 1996: Zur Datierung des Laokoon und der Skyllagruppe aus Sperlonga, in: JDAI 111, 139-223.

Kunze, C. 1998: Der Farnesische Stier und die Dirkegruppe des Apollonios und Tauriskos, JDAI Ergänzungsheft 30, Berlin.

Kunze, C. 2002: Zum Greifen nah, München.

Künzl, E. 1968: Frübhellenistische Gruppen, Köln.

Künzl, E. 1969: Der augusteische Silbercalathus im Rhenischen Landesmuseum Bonn, in: BJ 169, 321-392.

Kyrieleis, H. et al. 1996: Der große Kuros von Samos, Samos 10, Bonn.

La Rocca, E. 1998: Artisti rodici negli horti romani, in: Cima - La Rocca, 1998, 203-274.

Lausberg, H. 1973: Handbuch der literarischen Rhetorik, 2nd edition, München.

Leach, E.W. 2000: Narrative Space and the Viewer in Philostratus' Eikones, in: MDAI(R) $107,237-251$.

Leibundgut, A. 1999: Von der Lüsternheit des Auges, in: Hellenistische Gruppen. Gedenkschrift für A. Linfert, Mainz.

Lorenz, T. 1979: Monte Cavallo. Ein Nymphäum auf dem Quirinal, in: Mededelingen van bet Nederlands Instituut te Rome 41, 43-57.

Manderscheid, H. 1981: Die Skulpturenausstattung der kaiserzeitlichen Thermenanlagen, Berlin.

Martin, H.G. 1987: Römische Tempelkultbilder, Roma.

Martin, J. 1974: Antike Rhetorik, Handbuch der Altertumswissenschaft 2.3, München.

Marvin, M. 1983: Freestanding Sculptures from the Baths of Caracalla, in: AJA 87, 347384.

Michel, C. 1974: Die Weisheit der Maler und Dichter in den Bildern des älteren Philostrat, Hermes 102, 457-466.

Möbius, H. 1970: Vier hellenistische Skulpturen, in: Antike Plastik 10, Berlin, 39-54.

Moltesen, M. 1998: The Sculptures from the Horti Sallustiani in the Ny Carlsberg Glyptotek, in: Cima - La Rocca, 1998, 175-202.

Morales, H. 1996: The Torturer's Apprentice: Parrhasius and the Limits of Art, in: Elsner, 1996, 183-199.

Moreno, P. (ed.) 1995: Lisippo. L'arte e la fortuna, exhibition catalogue Rome, Milano.

Müller, F.G.J.M. 1994: The So-called Peleus and Thetis Sarcophagus in the Villa Albani, Amsterdam.

Muth, S. 1998: Erleben von Raum, leben im Raum. Zur Funktion mythologischer Mosaikbilder in der römisch-kasierzeitlichen Wohnarchitektur, Heidelberg. 
Neudecker, R. 1985: Review of: Manderscheid, 1981, Gnomon 57, 171-178.

Neudecker, R. 1988: Die Skulpturenausstattung römischer Villen in Italien, Mainz.

Newby, Z. 2002a: Reading Programs in Graeco-Roman Art, in: Fredrick, D. (ed.): The Roman Gaze, Baltimore 2002, 110-148.

Newby, Z. 2002b: Sculptural Display in the so-called Palaestra of Hadrian's Villa, in: $M D A I(R)$ 109, 59-82.

Noack-Hilgers, B. 1999: Philostrat der Jüngere, Gemäldebeschreibungen. Aus der Werkstatt der Analyse seiner Beschreibungstechnik, in: Thetis 5-6, 203-219.

Österberg, I. 1999: Demonstrating the Conquest of the World, in: Opuscula Romana 24, 155-162.

Pape, M. 1975: Griechische Kunstwerke aus Kriegsbeute und ibre öffentliche Aufstellung in Rom, Hamburg.

Pelikan, O. 1965: Vom antiken Realismus zur spätantiken Expressivität, Praha.

Piranomonte, M. 1998: Terme di Caracalla, Roma.

Piranomonte, M. 1999: Thermae Antoninianae, in: Steinby, E.M. (ed.): LTUR 5, Roma, 42-48.

Pirson, F. 1997: Style and Message on the Column of Marcus Aurelius, in: PBSR 64, 139179.

Pozzi, E. et al. (eds.) 1991: Il Toro Farnese. La “montagna di marmo" tra Roma e Napoli, Napoli.

Raeder, J. 1983: Die statuarische Ausstattung der Villa Hadriana bei Tivoli, Frankfurt a.M.

Reitz, C. - Egelhaaf, U. 1997 : Ekphrasis, in: DNP 3, Stuttgart, 942-950

Reusser, C. (ed.) 2001: Griechenland in der Kaiserzeit. Neue Funde und Forschungen zu Skulptur, Architektur und Topographie, Hefte des Archäologischen Seminars der Universität Bern, Beiheft 4, Bern.

Ridgway, B.S. 1985: Roman Copies of Greek Sculpture, Ann Arbor.

Ridgway, B.S. 2000: The Sperlonga Sculptures. The Current State of Research, in: de Grummond, N.T (ed.): From Pergamon to Sperlonga, Berkeley 2000, 78-91.

Rossbach, O. 1895: Athamas und Learchos, in: $M D A I(\mathrm{R}) 10,240-243$.

Rüpke, J. : Epideixis, in: DNP 3, Stuttgart 1997, 1101-1102.

Russell, D.A. 1983: Greek Declamation, Cambridge.

Savignoni, L. 1901: Roma IV: Nuove scoperte nella città, in: Notizie degli scavi, 247-253.

Schalles, H.-J. 1985: Untersuchungen zur Kulturpolitik der pergamenischen Herrscher, Istanbuler Forschungen 36, Tübingen.

Scheid J. - Huet, V. (eds.) 2000: Autour de la colonne Aurélienne, Turnhout.

Schmeling, G. (ed.) 1996: The Novel in the Ancient World, Leiden.

Schmitz, T. 1997: Bildung und Macht. Zur sozialen und politischen Funktion der zweiten Sophistik in der griechischen Welt der Kaiserzeit, Zetemata 97, München.

Schneider, W.J. 1998: Philologisch-kunstgeschichtliche Bemerkungen zu drei Stücken der „Anthologia Latina“, in: Arctos 32, 225-233. 
Schönberger, O. 1995: Die 'Bilder' des Philostratos, in: Boehm - Pfotenhauer, 1995, 157 176.

Simon, E. 1954: Die Typen der Medeadarstellung in der antiken Kunst, in: Gymnasium 61, 203-227.

Slater, J. 1998: Passion and Petrification: The Gaze in Apuleius, in: CPh 93, 18-48.

Smith, R.R.R. 1998: Cultural choice and political identity in honorific portrait statues in the Greek east in the second century A.D., in: JRS 88, 56-93.

Spyropoulos, G. 2001: Drei Meisterwerke der griechischen Plastik aus der Villa des Herodes Atticus zu Eva, Loukou, Frankfurt a.M..

Stähli, A. 1998: Sammlungen ohne Sammler, in: Assmann, A. (ed.): Sammler, Bibliophile, Exzentriker, Tübingen 1998, 55-85.

Stähli, A. 1999: Die Verweigerung der Lüste, Berlin.

Steinmetz, P. 1982: Untersuchungen zur römischen Literatur des 2. Jhs. n. Chr., Paligensia 16, Wiesbaden.

Stemmer, K. 1971: Fragment einer kolossalen Panzerstatue Domitians? Zur Kolossalität in flavischer Zeit, in: $A A, 563-580$.

Stemmer, K. (ed.) 1988: Kaiser Marc Aurel und seine Zeit, exhibition catalogue Berlin, Berlin.

Stephan, E. 2002: Honoratioren, Griechen, Polisbürger, Hypomnemata 143, Göttingen.

Stewart, A. 2003: Hellenistic Art, in: Erskine, A. (ed.): A Companion to the Hellenistic World, Oxford 2003, 494-514.

Strong, D. 1976: Roman Art, Hardmondsworth.

Swain, S. 1996: Hellenism and Empire. Language, Classicism, and Power in the Greek. World A. D. $50-250$, Oxford.

Talamo, E. 1998: Gli horti die Sallustio a Porta Collina, in: Cima - La Rocca, 1998, 113169.

Tobin, J. 1997: Herodes Attikos and the City of Athens, Amsterdam.

Traversari, G. 1986: La statuaria ellenistica del Museo Archeologoico di Venezia, Roma.

Ulisse 1996: Andreae, B. (ed.): Ulisse. Il Mito e la memoria, exhibition catalogue Rome, Roma.

Vermeule, C.C. 1977: Greek Sculpture and Roman Taste, Ann Arbor.

von den Hoff, R. in print: “Achill das Vieh"? Strategien der Problematisierung transgressiver Gewalt in klassischen Vasenbildern, in: Moraw, S. - Fischer, G. (eds.): Die andere Seite der Klassik: Gewalt im 5. und 4. Jh. v. Chr., colloquium Bonn 2002, in print.

von Mercklin, E. 1962: Antike Figuralkapitelle, Berlin.

von Mosch, C. 1999: Bilder zum Rubme Athens. Aspekte des Städtelobs in der kaiserzeitlichen Münaprägung Athens, Milano.

Vorster, C. 1993: Vatikanische Museen. Museo gregoriano profano ex lateranense. Katalog der Skulpturen 2, Mainz. 
Vorster, C. 2003: Römische Gruppen des späten Hellenismus im Museo Gregoriani Profano des Vatikan, in: Zimmer, D. (ed.): Neue Forschungen zur hellenistischen Plastik. Kolloquium zum 70. Geburtstag von Georg Daltrop, Eichstätt 2003, 97-120.

Walker, S. (ed.) 1989: The Greek Renaissance in the Roman Empire, colloquium London, London.

Welcker, F.G. 1849: Alte Denkmäler 1, Göttingen.

Winkler, J.J. 1985: Auctor \& Actor, Berkeley.

Wistrand, M. 1992: Entertainment and violence in ancient Rome. The attitudes of the Roman writers in the first century A.D., Göteborg.

Woolf, G. 1994: Becoming Roman, Staying Greek. Culture, Identity and the Civilizing Process in the Roman East, in: PCPhS 40, 116-143.

Zanker, G. 2004: Modes of Viewing in Hellenistic Poetry and Art, Madison.

Zanker, P. 1974: Klassizistische Statuen, Mainz.

Zanker, P. 1979: Zur Funktion und Bedeutung griechischer Skulptur in der Römerzeit, in: Flashar, 1979, 283-306.

Zanker, P. 1991: Collezione ed affetto nelle Terme di Caracalla, in: Pozzi, 1991, 43-46.

Zanker, P. 1995: The Mask of Socrates. The Image of the Intellectual in Antiquity, Berkeley.

Zanker, P. - Ewald, B. 2004: Mit Mythen leben. Die Bilderwelt der römischen Sarkophage, München.

Zumbo, A. 1998: L'ekphrasis d'opera d'arte. Esercitazione letterario o strumento di communicazione?, in: Arslan, E.A. et al. (eds.): La 'parola' delle immagini e delle forme di scrittura, Messina 1998, 29-40. 